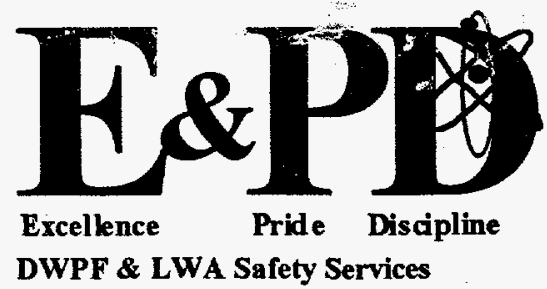

June 6, 1994

EPD-LWS-94-0012

To: B. G. Croley, 241-120H

From: J. D. Menna, 992-1W Ypor

Safety Evaluation of the ITP Filter/Stripper Test Runs and Quiet Time Runs Using Simulant Solution (U)

The E\&PD and WSRC review process for the Safety Evaluation of the ITP Filter/Stripper Test Runs and Quiet Time Runs Using Simulant Solution (U), WSRC-TR-92-427, Rev 3, is complete. The comments were resolved and incorporated as appropriate.

SRTC, E\&PD, ESH\&QA, and Waste Management Safety Review Committee (WMSRC) have approved the document.

If you have any questions, please contact M. K. Gupta of my staff.

CC: $\quad$ G. T. Wright, 703-H

R. A. Scaggs, 703-H

B. L. Lewis, 703-H

C. J. Baker, $5002 \mathrm{H}$

G. D. Thaxton, $241-120 \mathrm{H}$

W. B. Van Pelt, 241-120H

R. M. Satterfield, 719-4A

B. S. Shapiro, 992-1W

R. F. Bradley, 992-2W

D. A. Pervis, 706-21C

M. L. Cowen, 992-1W

M. K. Gupta, 992-1W

T. E. Britt, 992-1W

V. S. O'Block, 992-2W

Kyo Kim, 992-2W

H. M. Handfinger, $5002 \mathrm{H}$

D. C. Wood, 706-21C 


\section{DISCLAIMER}

Portions of this document may be illegible in electronic image products. Images are produced from the best available original document. 


\title{
Safety Evaluation of the ITP Filter/Stripper Test Runs and Quiet Time Runs Using Simulant Solution (U)
}

by

\author{
M. K. Gupta
}

Westinghouse Savannah River Company

Savannah River Site

Aiken, South Carolina 29808

DOE Contract No. DE-AC09-89SR18035

This paper was prepared in connection with work done under the above contract number with the U.S.

Department of Energy. By acceptance of this paper, the publisher and/or recipient acknowledges the U.S. Government's right to retain a nonexclusive, royalty-free license in and to any copyright covering this paper, along with the right to reproduce and to authorize others to reproduce all or part of the copyrighted paper. 


\section{DISCLAIMER}

This report was prepared as an account of work sponsored by an agency of the United States Government. Neither the United States Government nor any agency thereof, nor any of their employees, makes any warranty, express or implied, or assumes any legal liability or responsibility for the accuracy, completeness, or usefulness of any information. apparatus, product, or process disclosed, or represents that its use would not infringe privately owned rights. Reference herein to any specific commercial product, process, or service by trade name, trademark. manufacturer, or otherwise does not necessarily constitute or imply its endorsement, recommendation, or favoring by the United States Government or any agency thereof. The views and opinions of authors expressed herein do not necessarily state or reflect those of the United States -Government or any agency thereof.

This report has been reproduced directly from the best available copy.

Available to DOE and DOE contractors from the Office of Scientific and Technical Information, P. O. Box 62, Oak Ridge, TN 37831; prices available from (615) $576-8401$.

Available to the public from the National Technical Information Service, U. S. Department of Commerce, 5285 Port Royal Rd., Springfield, VA 22161 
SAFETY EVALUATION OF THE ITP FILTER/STRIPPER TEST RUNS AND QUIET TIME RUNS USING SIMULANT SOLUTION (U)

M. K. Gupta

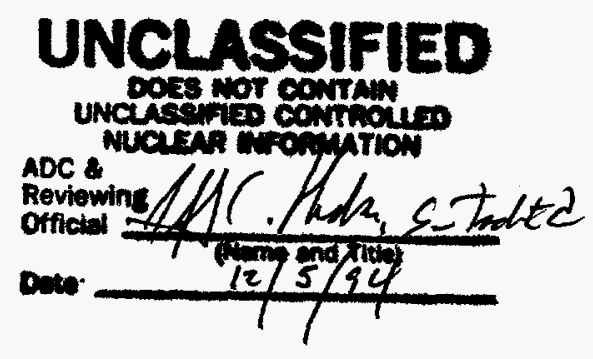

June 1994

Westinghouse Savannah River Company Savannah River Technology Center Aiken, SC 29808 
Key Words: Safety Evaluation

Benzene.

Simulant runs

ITP

Filter/Stripper test

SAFETY EVALUATION OF THE ITP FILTER/STRIPPER TEST RUNS AND

QUIET TIME RUNS USING SIMULANT SOLUTION (U)

M. K. Gupta

June 1994

Westinghouse Savannah River Company

Savannah River Technology Center

Aiken, SC 29808 
APPROVALS:

$\frac{\text { MYupt }}{\text { M. K. Gupta }}$

M. K. Gupta, Author

1. B. 3ute

T. E. Britt, Lead Engineer

$\frac{10 \text { thth }}{\text { S.U. Nathan, Reviewer }}$

$\frac{\text { AD Menma }}{\text { J. Menna, Manager, DWPF/HLW Group }}$

Kथ\&

L. A. Wooten, Manager, DBA/Pheno. Group

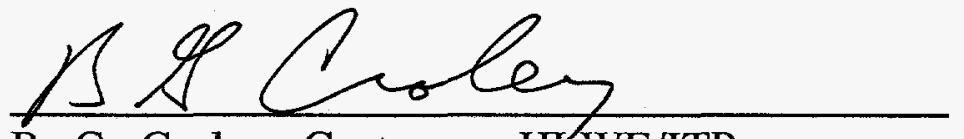

B. G. Croley, Customer, HKWE/ITP

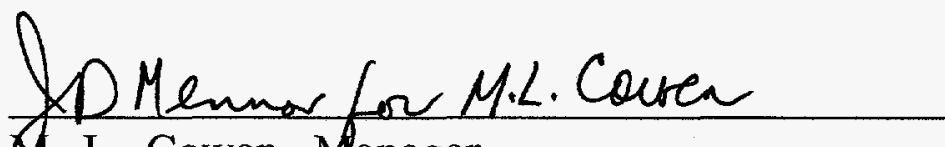

A. L. Cowen, Manager,

Safety Services S Section $\frac{6 / 2 / 94}{\text { Date }}$

$6 / 2 / 94$

Date

$\frac{6 / 2 / 94}{\text { Date }}$

$\frac{6 / 2 / 94}{\text { Date }}$

$4 / 54$

$\frac{6 / 6 / 94}{\text { Date }}$

$\frac{6 / 3 / 94}{\text { Date }}$ 


\section{REVISION LOG}

$\begin{array}{cc}\text { Revision Date } & \begin{array}{l}\text { Changes } \\ \text { It included the addition of Tri-N-Butyl Phosphate } \\ \text { (TBP) as a defoamer for simulant runs and transfer of } \\ \text { 'Information Only' Simulant Solution and inhibited } \\ \text { water to Tank 48. }\end{array} \\ 3 & 10 / 93 \quad \begin{array}{l}\text { It included the modifications to the Feed Tank. } \\ \text { The accident, Benzene/BuOH Deflagration in the } \\ \text { Feed Tank, was revised to include the consequences } \\ \text { of the failure of the Feed Tank. }\end{array} \\ & \begin{array}{l}\text { It includes the addition of TBP injection system, new } \\ \text { backpulse system, and addition of oxygen } \\ \text { monitoring system in the Stripper Building. Hazards } \\ \text { of these new modifications are analyzed. It also } \\ \text { analyzes the transfers of salt solution from the tanker } \\ \text { truck to the Feed Tank, filtrate to Tank 50, and spent } \\ \text { simulant solution to Tank 48. }\end{array}\end{array}$


CONTENTS

PAGE

1.0 Introduction and Summary .................................................................. 7

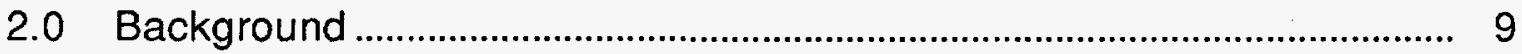

2.1 Process Description ....................................................................... 9

3.0 Filter/Stripper Test Runs and Quiet Time Runs Program ........................... 11

3.1 Program Scope .............................................................................. 11

3.2 Temporary Equipment Used for Filter/Stripper Test Runs and Quiet Time Runs Program ......................................................... 12

3.3 Simulant Selection and Preparation............................................... 13

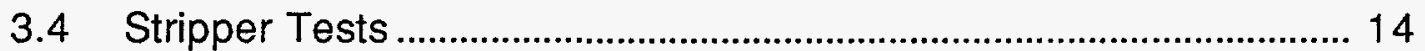

3.5 Stripper and Filter Performance Tests.............................................. 14

3.6 Quiet Time Runs Program............................................................. 15

3.7 Equipment Cleaning and Storage.................................................. 15

3.8 Disposition of Water Flushes \& Simulants ........................................ 15

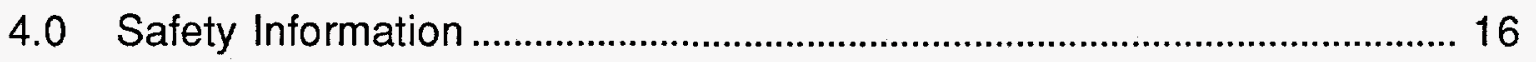

4.1 Chemical Spill at Temporary Facility ................................................. 17

4.2 Entire Feed Tank Spill/Fire ............................................................. 19

4.3 Nitrogen Asphyxiation in Stripper Building...................................... 20

4.4 Benzene Release into Stripper Building ............................................ 21

4.5 Benzene/1-Butanol Deflagration in Feed Tank................................ 22

4.6 Benzene Deflagration/Release During the Column Cleaning ........ 24

4.7 Filter Cell Deflagration and Fire ...................................................... 26

4.8 Feed Solution Spill Due to the Over Pressurization of the Transfer Hose .............................................................................. 27

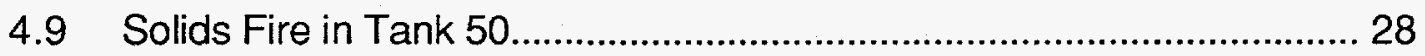

4.10 Corrosive Flush Solution Added to Tank 50 or Tank 48................ 29

4.11 Deflagration in Filtrate Hold Tank..................................................... 30

4.12 Flush Solution (Containing Oxalic Acid) Inadvertently

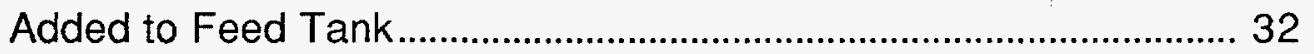

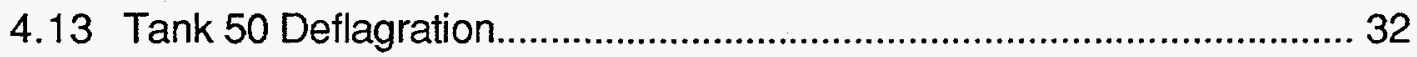

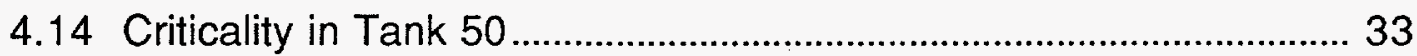

4.15 Deflagration in TBP Tank .......................................................... 33

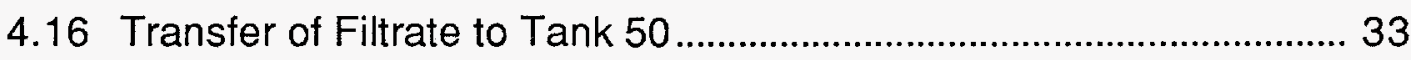

4.17 Transfer of 'Information Only' Simulant Solution, Inhibited Water, and Spent Simulant Solution to Tank 48............................. 33 
4.18 Releases During Normal Operations.................................................. 37

4.19 Damage to the Permanent ITP and Tank Farm Facilities................ 38

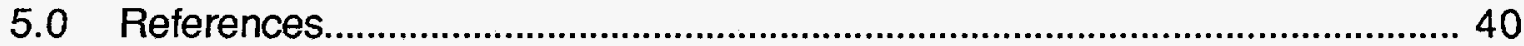

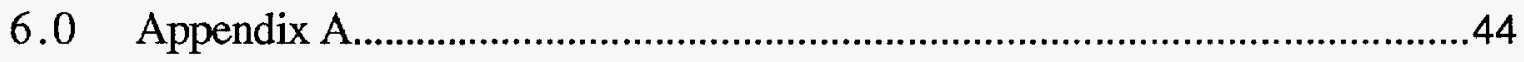




\section{SAFETY EVALUATION FOR THE ITP SIMULANT RUNS}

1.0 Introduction and Summary

The purpose is to provide the technical bases for the evaluation of Unreviewed Safety Question for the In-Tank Precipitation (ITP) Filter/Stripper Test Runs (Ref. 7) and Quiet Time Runs Program (described in Section 3.6). The Filter/Stripper Test Runs and Quiet Time Runs program involves a 12,000 gallon feed tank containing an agitator, a 4,000 gallon flush tank, a variable speed pump, associated piping and controls, and equipment within both the Filter and the Stripper Building.

The safety bases consist of:

- Pre-operational Process Hazard Report, In-Tank Precipitation (Temporary Cold Run Facility) (Ref. 1)

- $\quad$ ITP Pre-Operational Process Hazard Review Report (Ref. 2)

- $\quad$ Draft (WSRC Approved) ITP Safety Analysis Report (SAR Addendum) (Ref. 3)

- $\quad$ Draft ITP (WSRC Approved) Operational Safety Requirements (OSR) (Ref. 4)

The chemical consequences of the accidents analyzed in Section 4 of this report are the release of volatile components, benzene, tributyl phosphate (TBP), and alcohol, and non-volatile components sodium titanate (ST), sodium tetraphenylborate (STPB), sodium hydroxide $(\mathrm{NaOH})$ and oxalic acid, to the atmosphere. The onsite (100 meters from the release) and offsite concentrations of volatile and nonvolatile chemicals from various potential accidents are less than the IDLH and 0.01 IDLH values (Ref. 17), respectively as shown in Tables 2 and 4 . The facility concentrations (10 meters and 20 meters for the surface and Feed Tank release, respectively) of volatile chemicals are below the IDLH values as shown in Table 7. The increase in lifetime Incremental Cancer Risk (ICR) values, for an onsite individual and an individual inside the stripper building from various accidents shown in Figure 5, are equal to or below the Low Hazard criteria in Facility Safety Analysis Manual (Ref. 22). The doses from the chemicals are within the existing safety envelope of the limited analysis performed in the approved Tank Farm SAR (Ref. 23) and draft ITP Addendum to the Tank Farm SAR (Ref. 3).

The 8-hour and 1-hour average maximum benzene and 1- butanol $(\mathrm{BuOH})$ concentrations at different locations in the ITP facility during pump operation, thermal cycling, and filtrate or salt solution transfer to the Feed Tank are shown in Tables 8 and 9, respectively. The 
BuOH concentrations are below the Occupational Safety and Health Administration (OSHA) limits. The benzene concentration (511 ppm) exceeds the Short Term Exposure Limit (STEL) of $5 \mathrm{ppm}$ at the Filter/Stripper building during filtrate or salt solution transfer to the Feed Tank which lasts 343 minutes ( $35 \mathrm{gpm}$ transfer rate). The 8hour average maximum concentration of benzene, during filtrate or salt solution transfer, pump operation, and thermal cycling, is above the action limit of $0.5 \mathrm{ppm}$ at the Filter/Stripper building. It is recommended that the access to the Filter/Stripper building (241$96 \mathrm{H})$ be controlled and limited during the entire test runs. The benzene concentrations must be monitored at building $241-96 \mathrm{H}$ and at other locations (up to 30 meters from the Feed Tank) in the ITP Facility to determine the areas where benzene concentration is above the STEL of $5.0 \mathrm{ppm}$ during filtrate or salt solution transfer and benzene dissolution. If the benzene concentration is above the STEL of $5.0 \mathrm{ppm}$ during filtrate or salt solution transfer or benzene dissolution, then the access to those areas will be controlled.

The concentration of flammables in vapor phase from all the solutions (of 'Information Only' Simulant Solution (already completed), 4 transfers of inhibited water solution, and 2 transfers of spent simulant solution) transferred to Tank 48 and the existing concentration of flammables in Tank 48 will be about $9 \%$ of LFL.

Considering the possibility of benzene/BuOH stratification in the vapor space of Tank 48 and of possible disturbance during the addition, the vapor space will be continuously monitored for LFL during the transfer and should the LFL increase significantly $(>10 \%$ of LFL), the transfer will be stopped.

A maximum of 100,000 gallons of up to $5.1 \mathrm{M}$ sodium salt solution (Table 1) transferred to Tank 50 during simulant runs will be inherently safe (Ref. 8).

The addition of TBP containing solutions to Tanks 48 or 50 do not create any criticality risk.

The worst onsite and offsite radiological consequences from accident 4.9, Solids Fire in Tank 50, are 5.4 rem and 8.9 E-3 rem, respectively and will occur at a frequency of $4.0 \mathrm{E}-4 / \mathrm{yr}$. The offsite and onsite consequences are significantly below the DOE/TIC-11603 guideline and WSRC 9Q guideline as shown in Figures 1.3 and 1.6, respectively of Reference 3 . The risk is within the existing safety envelope of the approved Tank Farm SAR (Ref. 23) and the draft ITP addendum to the Tank Farm SAR (Ref. 3). 
The risk to the Tank Farm facilities from the accidents postulated from Filter/Stripper Test Runs and the Quiet Time Runs including, Benzene/BuOH Deflagration in Feed Tank and Solids Fire in Tank 50 , are bounded by the risk in the Tank Farm SAR (Ref. 23).

The Filter/Stripper Test Runs and Quiet Time Runs can be performed without undue risk to operating personnel, the public, or the environment.

$2.0 \quad$ Background

In-Tank Precipitation is a process for removing radioactivity from the salt stored in the Waste Management Tank Farm. The process involves precipitation of cesium and potassium with sodium tetraphenylborate (STPB) and adsorption of strontium and actinides on insoluble sodium titanate (ST) particles; Cs-137 comprises the majority of the radioactive material present in the waste salt. Adding ST and STPB to the salt solution forms a slurry, with approximately $99.9 \%$ of the activity trapped in insoluble solids (Ref. 5). These insolubles consist of precipitated potassium tetraphenylborate (KTPB) and cesium tetraphenylborate (CsTPB), as well as strontium and actinides adsorbed on ST particles. The slurry will be concentrated from 0.5 weight percent solids to approximately 10 weight percent solids using cross flow micro-filtration. The filtrate, also known as low activity or decontaminated salt solution, contains volatile organic compounds which are formed during the precipitation process. The volatile compounds are removed by humidified nitrogen as the filtrate is passed through a stripping column. The Saltstone Facility in $\mathrm{Z}$ area will perform the final processing of the decontaminated salt solution while the Defense Waste Processing Facility in S-Area will perform the final processing of the concentrated slurry.

\subsection{Process Description}

Saltcake accumulated in the tank farm storage tanks is dissolved with inhibited water (well water mixed with sodium hydroxide and sodium nitrite as corrosion inhibitors) and transferred to Tank 48 for processing (Figure 1). Tank 48 is the waste tank where the precipitation and adsorption process occurs. The slurry from Tank 48 is concentrated to 10 weight percent solids by repeated filtration. The concentrated precipitate is then washed with inhibited water from cold feeds to remove soluble salts. The washed precipitate is transferred from Tank 48 to Tank 49 for temporary storage before feeding it to S-Area for final disposal. The decontaminated salt solution produced from the filtration is sent to Tank 50 for eventual transfer to Z-Area. The spent wash water is transferred to Tank 22 to be used as dilution water for the next cycle. Because of the flammable vapors and combustible solids hazards associated with 
the organics produced by the precipitation process, both Tanks 48 and 49 have been provided with a nitrogen purge system.

The cross-flow micro-filters used for ITP are housed in stainless steel lined, concrete cells within the Filter Building. The ITP process uses two filters in a parallel arrangement. The filters are similar in appearance to shell and tube heat exchangers with the tubes acting as the filter media. The tubes in the filters are constructed of sintered $316 \mathrm{~L}$ stainless steel powder. Slurry enters on the tube side of the filter. The pressure differential between the inside of the tubes and the shell side of the filter pushes clear liquid through the porous tube walls. The porous tubes are rated at 0.5 micron to achieve the desired decontamination factor. The filtrate produced is essentially free of cesium and strontium insolubles. The flow of slurry through the tubes helps prevent the buildup of particles on the tube walls, thereby helping to reduce the plugging of the filter. To prevent excessive solids build up on the tubes, periodic backpulsing is utilized. A backpulse is a temporary reversal of filtrate flow accomplished by applying a pulse of high pressure nitrogen (50 to 85 psi higher than tube side liquid pressure) to the liquid on the shell side of the filter. This temporary reversal in filtrate flow dislodges the layer of particles adhering to the inner surface of the filter tubes. During normal filtration operation, the frequency of the backpulses will be controlled by the pressure differential across the tubes.

The filtrate production rate is controlled using valves on both tube and shell sides of the filter. These control valves permit the adjustment of the liquid pressure drop across the filter media. This pressure drop is the driving force for filtrate production. Slurry is continuously recycled from the processing tank, to the filters, and back to the processing tank (Tank 48). Filtrate flows from the shell side of the filter to a stripper column. Backpulse chambers, which are off-line except during backpulse operation, provide a reservoir of filtrate so the backpulse is accomplished with liquid and not gas; this is the most efficient method of backpulsing. From the filter, the filtrate flows to the stripping columns to remove volatile organic compounds (alcohols and benzene). After the filter, tributyl phosphate (TBP) is injected in to control foaming in the stripper.

The TBP is injected into the filtrate supply lines, leading to each of the stripper columns, by an electrically operated diapharagm pump. The TBP feed pump and back-up feed pump are located adjacent to the 120 gallon TBP tank on the lower level of the hold tank room. Level alarms in the tank are provided.

The filtrate enters a stripping column at the top and flows downward through the column packing as humidified nitrogen enters at the bottom and flows upward. The organic compounds tend to diffuse from the filtrate into the nitrogen. The organic laden nitrogen is then 
passed through the High Efficiency Mist Eliminator (HEME) and HEPA filters to remove droplets and contaminants before being released to the atmosphere. The filtrate is pumped from the bottom of the column to the filtrate hold tanks.

The two 12,000 gallon filtrate hold tanks are located in the Filter Building. Because of the potential for the presence of flammable organic vapors, the hold tanks are equipped with nitrogen blankets. Proper operation of the stripping columns will prevent the buildup of a dangerous concentration of flammable vapors in the hold tanks. Nitrogen blankets are provided as an additional safety measure.

The presence of flammable and inert gas sources in the Stripper Building constitutes a potential personnel hazard. An oxygen monitoring system is provided to detect and warn personnel of the presence of a low, unsafe level of oxygen in the building atmosphere. The Stripper Building Oxygen Monitor consists of 16 fuel cell based sensors distributed through all three levels of the Stripper Building and Hold Tank Room. All 16 sensors are monitored by a central controller located in the Crane Control Room. The central controller generates set point and failure alarms which are transmitted to the 241-82H Distributed Control System (DCS) and $7400 \mathrm{~B}$ hardwired alarm panel. The alarm condition also sets off warning lights and horns at the exits to the building.

3.0 Filter/Stripper Test Runs and Quiet Time Runs Program

3.1 Program Scope

The primary objective of the Filter/Stripper Test Runs and Quiet Time Runs program is to ensure that the facility will fulfill its design basis function prior to the introduction of radioactive feed.

The safety envelope for ITP Filter/Stripper Test Runs and Quiet Time Runs consists of the applicable PHR actions from PHR 200-H-486 (designated in the ITP Punchlist), all PHR actions from PHR 200-H493, the intent of applicable ITP Operational Safety Requirements (defined in WER-ITP-920265) and the mitigation measures listed in Section 4 of this document. The interface between the ITP Temporary Facility and Tank 48 and 50 is addressed by the mitigation measures listed in Section 4 of this document and in Test Authorizations WSRC-TA-91-0005-11 (Ref. 31) and WSRC-OX-89-15-001, Rev. 6 (Ref. 8), respectively. Limited transfers from the Feed Tank to Tank 48 are included in Section 4.17. Transfer from the Flush Tank (containing neutralized oxalic acid) to Tank 50 are allowed 30 times during the tests. A maximum of 100,000 gallons of up to $5.1 \mathrm{M}$ sodium salt solution can be transferred to Tank 50 during simulant runs as discussed in Section 4.16. 
The filter/stripper test program consists of three parts:

(1) Information Only Tests - One stripper will be tested using salt solution ( 3.0 molar sodium) spiked with benzene and TBP. This test will provide information on the relationship between TBP and the pressure drop across the column. This part of the program has already been completed.

(2) Stripper Performance Evaluation - Both strippers will be tested using salt solution spiked with benzene; no solids will be present during this phase of testing.

(3) Stripper and Filter Performance Evaluation - The strippers and filters will be tested using approximately $10 \mathrm{wt} \%$ solids slurry. The filter flux testing will be performed to determine the effectiveness of filter cleaning.

Cleaning of the system may be performed after completion of all tests unless filter or stripper performance shows evidence of degradation that would require an earlier cleaning.

3.2 Temporary Equipment Used for Filter/Stripper Test Runs and Quiet Time Runs Program

Construction of the temporary facilities to be used during this program has been completed (Ref. 6). These facilities include a simulant feed tank, chemical addition system, temporary filter feed pump, slurry return line, filtrate return line, simulant recovery system, and flush tank (Figure 2).

The feed tank has a working capacity of 12,000 gallons. It is equipped with a single speed agitator to assure thorough mixing of tank contents. The tank is constructed of $304 \mathrm{~L}$ stainless steel. The tank is provided with an overflow line with a seal leg. The overflow discharges within the dike surrounding the temporary facilities. The feed tank is provided with a nitrogen blanket to address flammability hazards associated with the chemical simulants. The nitrogen source is a $10 \mathrm{psig}$ header. The nitrogen blanket regulator set point is approximately +0.5 inches of water column. At pressures less than $0.5^{\prime \prime} \mathrm{WC}$, the nitrogen supply valve will remain open. A pilot actuated regulator and a regulator by-pass line to facilitate initial tank inerting are provided. Following the initial nitrogen purge (and subsequent nitrogen purges if the blanket is lost), the oxygen concentration is verified to meet the requirement in Reference 3 using a portable oxygen analyzer. Thereafter, the nitrogen blanket pressure is maintained positive to ensure that the oxygen concentration remains 
within requirements. ${ }^{*}$ The Feed Tank was designed for an internal pressure of less than 15 psig (Ref. 29). The tank is fitted with a conservation vent for routine pressure relief ( $2 \mathrm{psig}$ ), a vacuum relief with flame arrestor, and an emergency vent for relief $(2.5 \mathrm{psig})$ of abnormal over pressurization. The tank is equipped with liquid level and vapor space pressure instrumentation. High and low blanket pressure alarms are provided. A conductivity probe (with alarm) is installed at the top of the tank to detect severe foaming of the slurry, should it occur. If foaming occurs, then the agitation and pumping will be stopped until foam dissipates.

A temporary filter feed pump will pump the simulant from the feed tank to the filter. The temporary pump is designed for low shear, slurry service. The variable speed drive for an actual ITP filter feed pump will be used to control the temporary pump, thus allowing use of system interlocks in place to prevent damage to the filters. Low feed tank level will shut off the temporary feed pump as will low flow in the temporary pump's discharge line. Pump speed is controlled from the ITP Control Room in $241-82 \mathrm{H}$.

Slurry is returned to the temporary feed tank through a stainless steel pipe. The discharge from this temporary return line is below the expected operating level of the feed tank to minimize foam formation.

Process piping will route filtrate from the filter to the seal tanks, to the stripper and then to the filtrate hold tanks. A stainless steel pipe is used to return the filtrate to the temporary feed tank. This temporary line is connected to the process piping downstream of the permanent filtrate pumps, thereby allowing their use during slurry runs to return filtrate to the temporary feed tank.

The temporary facilities include a nitrogen blanketed flush tank ${ }^{*}$ to temporarily hold flush water used to clean the system. The tank is equipped with a conservation/vacuum vent with a flame arrrestor and an emergency vent. Tank instrumentation includes level indication and blanket pressure. Both high and low blanket pressure alarms are provided.

3.3 Simulant Selection and Preparation

\footnotetext{
* The only exception will be for inspection access into the tank after the tank atmosphere has been verified to have a benzene concentration of less than $10 \%$ of Lower Flammability Limit (LFL). After the inspection, the oxygen concentration will be restored to within requirements.
} 
For 'Information Only' tests, approximately 8000 gallons of $3.0 \mathrm{M}$ sodium salt solution will be pumped through the system with benzene and TBP added and maintained near solubility levels.

For Stripper Performance Evaluation, approximately 12,000 gallons of salt solution will be added to the simulant Feed Tank. Table 1 contains the salt solution composition for the stripper test runs. The salt solution will be spiked with benzene to perform the stripper tests. Data will be taken on the stripper columns using a solution that contains up to 20 gallons of benzene in the Feed Tank.

For Stripper and Filter Performance Evaluation, sodium tetraphenylborate (STPB) will be added (and maybe sodium titanate (ST) also) to the salt solution to initially form an approximately $1.5 \mathrm{wt}$ $\%$ solids mixture. Solids (potassium tetraphenylborate, or KTPB) are formed by a precipitation reaction of the potassium in the salt solution and the STPB. The detailed composition of the simulant is presented in Table 1. The Material Safety Data Sheets (MSDS) are available in the $241-82 \mathrm{H}$ control room. The procedures for chemical addition and chemical unloading include personnel protection appropriate for chemical exposure hazards. These procedures have been reviewed by an Industrial Hygienist.

3.4 Stripper Tests

The tests involve running the ITP filters with either decontaminated salt solution (DSS) stripper (column 1) or the wash water (WW) stripper (column 2) and collecting stripper bottoms in a Filtrate Hold Tank (Ref. 7).

3.4.1 For 'Information Only' stripper columns testing, benzene will be added to the simulant Feed Tank via a small chemical addition pump to achieve the "worst" case concentrations of approximately $450 \mathrm{ppm}$ (Ref. 27).

3.4.2 For stripper column acceptance tests, benzene will be added to the Feed Tank via a small chemical addition pump to achieve a total volume of up to 20 gallons of benzene in the Feed Tank.

3.5 Stripper and Filter Performance Tests

The tests involve filtrate production and concentration of the simulant in the simulant Feed Tank. The filter efficiency and filter flux (gpm filtrate/sq ft filter area) will be evaluated. To prevent excessive solids buildup on the filter media, periodic backpulsing will be utilized.

3.5.1 An approximately $1-4 \mathrm{wt} \%$ solids concentration simulant will be initially prepared by adding STPB (and maybe ST also) to the salt 
solution. The filter will be tested using solids concentrations from approximately 1 - $10 \mathrm{wt} \%$ solids (Ref. 7 ).

3.6 Quiet Time Runs Program

The Quiet Time Runs Program consists of a series of training exercises where filtration, benzene stripping, filtrate hold tank transfers, and component cleaning operations are performed. These training exercises will follow Filter/Stripper Test Runs and will use the same equipment configuration and safety controls as Filter/Stripper Test Runs. The training exercises will include both normal process operations, support operations such as Filter/Stripper Building ventilation and simulated alarms or off-normal operations. Alarms and off-normal conditions will be simulated by written or verbal communication rather than by instrument or process manipulation.

3.7 Equipment Cleaning and Storage

When the system is shut down after filter, stripper or Quiet Time Runs, the simulant will be transferred to the Feed Tank. Cleaning operations, as needed, will be performed on the filters, hold tanks and the strippers as the final segment of Simulant Runs and Quiet Time Runs, in preparation for storage of the equipment while the system is prepared for the beginning of "hot" runs. Cleaning will also be performed should the filters or strippers become unacceptably fouled (i.e. high differential pressure). Water and oxalic acid will be used for cleaning, and the waste cleaning solution, after it is neutralized with caustic, will be transferred to Tank 50 .

3.7.1 If required, the filters will be cleaned, by initially flushing the filter tubeside with water while backpulsing as needed, then cleaning/backpulsing with oxalic acid (OA). After the OA cleaning, the filters will be flushed/backpulsed with water again from the shell side.

3.7.2 The strippers will be cleaned in the same way as the filters, by filling with water, cleaning with $O A$ and filling with water.

3.7.3 If required, the Hold Tanks will be cleaned using the installed rotary sprayers to flush the tank walls with water and OA solutions. The filter cell sump will not be cleaned unless material is spilled in the sump.

3.7.4 If cleaning is conducted during the test program, the filter or stripper will be left in wet lay-up until the next test. After all testing has been completed, the filters and strippers will be cleaned and left in wet or dry lay-up.

3.8 Disposition of Water Flushes \& Simulants 
3.8.1 During simulant runs it will be necessary to transfer flush water and cleaning solutions from the Flush Tank to Tank 50. All solutions will be sampled and analyzed for chemicals and $\mathrm{pH}$ prior to transfer to ensure that the liquid meets the requirements (see note) listed in the Test Authorization (Ref. 8) and Technical Standards (Ref. 9) governing these transfers.

Note: Alcohol analyses will not be required until sodium titanate is introduced into the test facility. Since the test solutions are not radioactive, radionuclide analyses will not be required.

3.8.2 After all the simulant runs are complete, the simulant will be collected in the Feed Tank. The Feed Tank will be isolated and the nitrogen blanket maintained until the solution is transferred to Tank 48. The 'Information Only' simulant solution (Table 10), 4 transfers of inhibited water (Table 11) solution, and 2 transfers of spent simulant solution (Table 12) to Tank 48 will be allowed (section 4.17 addresses their hazards in Tank 48). After these transfers, the pipe from the Feed Tank to Tank 48 will be isolated.

\subsection{Safety Information}

This section addresses new risks associated with the filter/stripper test runs and quiet time runs program in the previously identified ITP facilities. This analysis does not address the risks associated with the radioactive operation of the permanent ITP facilities; these risks are addressed in the draft ITP Addendum (Ref. 3). The filter/stripper test runs and quiet time runs will operate the permanent ITP facilities in about the same manner as actual ITP operation. The intent of the applicable OSRs will be implemented through procedures even though the draft OSRs (Ref. 4) are not approved (Ref. 39). In addition, the Process Hazards Review (PHR) for the temporary facilities (Ref. 1), PHR for Tank 50 transfers (Ref. 10) and TA for those transfers (Ref. 8) have been completed.

The risks associated with the filter/stripper test runs and quiet time runs program of ITP include:

- hazards, both personnel and environmental, associated with handling the chemical simulants

- the presence of flammable materials

- the potential for damage to the permanent ITP and Tank Farm facilities

The risks, potential accident scenarios, and safeguards either in place or planned are discussed at length below. 
4.1 Chemical Spill at Temporary Facility

Background The following cold chemicals are used during simulant runs:

1. Benzene ( $22 \times 5$ gallons)

2. Sodium titanate (ST) (contains up to 3 volume percent of methyl and/or isopropyl alcohol) ( $3 \times 55$ gallons) may be used

3. Sodium tetraphenylborate (STPB) (contains up to $650 \mathrm{ppm}$ of benzene) (5000 gallons)

4. Oxalic acid (up to 4 weight percent) (1000 gallons)

5. $\mathrm{NaOH}$ (up to 25 weight percent) (1000 gallons)

6 . Salt Solution $(12,000$ gallons for a Stripper Performance run) Performance run)

(8000 gallons for a Stripper and Filter

7. Tributyl Phosphate (TBP) $(1 \times 55$ gallons $)$

The 22 bottles ( 5 gallon each) of benzene are analyzed in the accident, but only 4 bottles at a time will be used during the simulant runs.

A 55 gallon drum of TBP is analyzed in the accident, but no more than 25 gallons will be injected during the entire simulant runs.

A spill to the dike may constitute a release reportable to certain governmental agencies, including the South Carolina Department of Health and Environmental Control (SCDHEC).

Initiators Some typical causes of accidental releases of chemicals are overflows, transfer errors and leaks.

Frequency Some historical data on leaks of chemicals supplied to waste disposal operations are taken from the 200-Area Fault Tree Data Bank (Ref. 13). The historical frequency is $6.1 \mathrm{E}-1 / \mathrm{yr}$. The duration of the entire program is only 3 months therefore, the frequency of spills is $5.1 \mathrm{E}-2 /$ month.

The probability of mishandling a 55 gallon drum of ST is $1.0 \mathrm{E}-2$ (Ref. 12). The number of ST drums handled during all the tests are 3 drums $/ 3$ months (estimate from WME). Therefore, the frequency of the spill of the entire 55 gallon drum is $1.0 \mathrm{E}-2 /$ month.

The probability of mishandling a 5 gallon bottle of benzene is $1.0 \mathrm{E}-2$ (Ref. 12). The number of benzene bottles handled during all the tests are 22 bottles/ 3 months (estimate from WME). Therefore, the frequency of the spill of the entire 5 gallon bottle is $7.3 \mathrm{E}-2 / \mathrm{month}$. 
The probability of mishandling a 55 gallon drum of TBP is $1.0 \mathrm{E}-2$ (Ref. 12). The number of drums handled during all the tests are 1 drum/3 months (Ref. 27). Therefore, the frequency of the spill of the entire 55 gallon drum is $3.3 \mathrm{E}-3 /$ month.

Consequences There are no radiological consequences to this event, because no radioactive material is present. The amount of material spilled is estimated from data in the Building 211-H SAR (Ref. 21). The average spill is estimated to be approximately $0.5 \%$ of the capacity stored and the consequences of a spill of 55 gallon drum of ST and TBP (Ref. 46) and a 5 gallon bottle of benzene also are calculated.

The onsite and offsite concentrations of volatiles (benzene, methanol, isopropanol, and TBP) and of non-volatiles ( $\mathrm{NaOH}$ and oxalic acid) contained in Tables 2 and 4 are below the IDLH and 0.01 IDLH values, respectively. The facility concentration of volatile chemicals are below the IDLH values as shown in Table 7 (Ref. 24). The duration of benzene release, shown in Table 3, is below the IDLH guideline (Ref. 17) as shown in Figure 4. The increase in lifetime Incremental Cancer Risk (ICR) values for an onsite and offsite individual are contained in Table 6 . Figure 5 shows that the ICR value for an onsite individual (Table 6 ) is below the Low Hazard criteria in Facility Safety Analysis Manual (FSAM) (Ref. 22). The criteria did not consider the duration of release.

The concentration of volatile chemicals in the solution will decrease as it evaporates and therefore, it will be a function of time. The calculated chemical release rates are for the initial chemical concentration of the spill from a time independent evaporation model. Therefore, the release rates, facility, onsite, and offsite concentrations, are conservative.

Mitigation Mitigation measures for this event include procedural controls to prevent solution overflows. The actions are to isolate the Flush Tank while chemicals are added to the Feed Tank, to prevent inadvertent draining of flush solution into the Feed Tank, to isolate the chemical addition tank from the chemical addition pump while filling the addition tank, to isolate the Feed Tank when pumping to and from Flush Tank and vice versa, and to stop the filter feed pump on high liquid level in the Feed or Flush Tanks. There are administrative controls for responding to chemical spills (Ref. 16). Interlocks are added to stop the filtrate pumps on high liquid level in Flush or feed tank.

The Feed Tank and Flush Tank are surrounded by a concrete dike sized to contain the contents of the tanks if they fail. 
Administrative and engineered controls will be used to ensure that no more than 25 gallons of TBP are injected during the entire simulant runs.

\subsection{Entire Feed Tank Spill/Fire}

Background The feed tank contains about 1-10 weight percent precipitate of KTPB in a salt solution which also contains benzene (up to 20 gallons), STPB, ST, (if used) and alcohol (present up to 3 volume percent in ST solution) and TBP (up to 55 gallons). Additional benzene will be generated by the thermal decomposition of STPB slurry in the Feed Tank (Ref. 25). A spill of the solution can expose workers to benzene and alcohol. If the spill is not cleaned up, the precipitate can dry out; and if there is a source of ignition, the dried precipitate can burn.

In the Feed Tank, some TBP may decompose by hydrolysis (in high $\mathrm{pH}$ solution) to form mono-and di-butyl phosphate and butyl alcohol (BuOH) (Ref. 32). One mole of TBP decomposes to 3 moles of $\mathrm{BuOH}$ (Ref. 33). The release of $\mathrm{BuOH}$ is analyzed but the release of monoand di-butyl phosphate is bounded by the release of undecomposed TBP.

Initiators The most likely initiator for this event is the removal of the cap from the wrong open-ended line and leaving the isolation valve on that line open.

Frequency The frequency for the spill of entire tank is $3.0 \mathrm{E}-4 / \mathrm{yr}$ as shown in Figure 3 or $2.5 \mathrm{E}-5 /$ month.

Consequences There are no radiological consequences to this event, because no radioactive material is involved. A liquid temperature of 60 degree Celsius was assumed in the Feed Tank (Ref. 27). The thermal decomposition of $1 \mathrm{wt}$. \% unwashed STPB slurry at 60 degree Celsius for 90 days can generate an additional $580 \mathrm{ppm}$ of benzene in the salt solution. Therefore, the final concentration of benzene in the salt solution is about $2250 \mathrm{ppm}$. The concentrations of flammables, benzene, methanol, isopropanol, $\mathrm{BuOH}$, and TBP, and of non-flammables, are shown in Tables 2 and 4 , respectively. The onsite and offsite concentrations are below the IDLH and 0.01 IDLH values, respectively. The facility concentrations of volatile chemicals are below the IDLH values as shown in Table 7 (Ref. 24). The duration of benzene release is below the IDLH guideline (Figure 4) and the ICR value for an onsite individual is below the Low Hazard criteria in FSAM (Figure 5). The concentrations are based on releasing the entire 12,000 gallons of salt solution (maximum) and 2,885 gallons of vapor (minimum) (Ref. 27) in the feed tank into the dike. The contribution of vapor release is about $5 \%$ to the total release. 
The onsite and offsite concentrations of volatile chemicals from the scenario 'Entire Feed Tank spill with minimum liquid' are bounded by the release of "Entire Feed Tank spill with maximum liquid' as shown in Reference 34.

The concentration of volatile chemicals in the solution will decrease as it evaporates and therefore, it will be a function of time. The calculated chemical release rates are for the initial chemical concentration of the spill from a time independent evaporation model. Therefore, the release rates, facility, onsite and offsite concentrations, and duration of the release are conservative.

The consequences of the fire would be the release of soot and other combustion products, possibly including acrid and/or hazardous 'partial' combustion products.

The consequences of a 12,000 gallons spill of salt solution (containing up to 20 gallons of benzene in the Feed Tank), used for Stripper Performance runs, would be the release of benzene. The benzene concentrations of this spill are bounded by the above simulant salt solution spill because it contains additional benzene present as an impurity and generated from thermal decomposition of STPB besides the 20 gallons added in the Feed Tank.

Mitigation Mitigation measures for this event include double isolation (two closed valves in series or a closed valve and pipe cap in series) on all drain paths such as sample lines, drain lines and vent lines (Ref. 18). Also, administrative controls are provided to keep valves closed and pipe caps installed except when the respective line is in use. There are administrative procedures for responding to spills (Refs. 15 and 16). The Feed tank is surrounded by a concrete dike sized to contain the contents of the entire Feed Tank, in the event of a tank failure. Fire hydrants, portable fire extinguishers, and a foam that prevents the evaporation of benzene are provided in the dike vicinity.

4.3 Nitrogen Asphyxiation in Stripper Building

Background Nitrogen is used as the stripping gas to remove benzene from filtrate. Should the nitrogen leak into the building, a worker entering the building can be subject to asphyxiation because of low oxygen in the air. The accident has already been analyzed in the draft ITP Addendum to the Tank Farm SAR (Ref. 3).

Initiators Large releases of nitrogen into the building can occur at numerous points, including the pressure relief valve on top of the column or an open drain line on the venturi separator in the nitrogen supply system (Ref. 3 ). 
Frequency The frequency is estimated as $2.2 \mathrm{E}-4 / \mathrm{yr}$. (Ref. 3 ) or $1.8 \mathrm{E}-5 /$ month.

Consequences The potential consequence of this accident is worker fatality if rescue and resuscitation are not successful. (Ref. 3 ).

Mitigation Mitigation measures include:

- Administrative controls are in place which require evacuation of the Stripper Building on loss of building exhaust, a sign-in in the control room to enter the building with normal ventilation, and $\mathrm{RCO}$ and/or IH coverage as necessary for entry when there is no ventilation.

- Oxygen monitors in the stripper building.

- Ventilation-fan-failed alarm lights at entry door.

4.4 Benzene Release into Stripper Building

Background The purpose of the stripping columns is to remove benzene from the filtrate in a counter-current flow of nitrogen. The column offgas contains benzene, but little oxygen. It is treated and vented along with the building ventilation exhaust as shown in Figure 2.14 of Reference 3. Workers can be exposed to benzene if the column offgas is released inside the building. This accident has already been analyzed in the draft ITP Addendum to the Tank Farm SAR (Ref. 3).

Initiators Large releases of offgas from a stripping column into the building can occur at the following points:

- The pressure relief valve (PRV) on top of the column

- Through the building ventilation system.

The PRV can fail to close after a pressure surge caused by a combination of high pressure in the nitrogen supply line and HEPA filter pluggage. The second initiator is a building ventilation fan failure, resulting in air reversal that draws column offgas from the stack through the ventilation ducts (Ref. 3).

Frequency The frequency for this event is 3.2E-5/yr (Ref. 3) or 2.7E-6/month.

Consequences The filtrate feed rate is approximately $115 \mathrm{gal} / \mathrm{min}$ with a maximum benzene concentration of approximately 1038 $\mathrm{mg} /$ liter at a sodium concentration of approximately 1.75M (Ref. 27). At higher sodium concentration, the benzene solubility decreases. 
Therefore, the benzene solubility at this sodium concentration (1.75M) is the bounding solubility for all the tests. It is assumed that the stripping is 100 percent efficient, and all the benzene stripped from the liquid phase is in the vapor phase. Thus, the maximum benzene release rate through the $50 \mathrm{ft}$ high stack during normal operation would be:

$(115 \mathrm{gal} / \mathrm{min}) \times(3.78 \mathrm{l} / \mathrm{gal}) \times(1038 \mathrm{mg} / \mathrm{l}) \times 1 \mathrm{~min} / 60 \mathrm{sec}$ $=7.52 \mathrm{E}+3 \mathrm{mg} / \mathrm{sec}$

The onsite and offsite concentrations of benzene during normal operations are shown in Table 2. The maximum benzene concentration is at 100 meters for a 50 feet high stack release (Ref. 24). The onsite and offsite concentration is below the IDLH and 0.01 IDLH value, respectively.

The offgas from the stripper column can be released through a pressure relief valve into the building air with a flow of $3000 \mathrm{ft}^{3} / \mathrm{min}$ (Ref. 7). Thus, the benzene concentration in the building air is:

$(7.52 \mathrm{E}+3 \mathrm{mg} / \mathrm{sec}) \times(60 \mathrm{sec} / \mathrm{min}) \times\left(35.31 \mathrm{ft}^{3} / \mathrm{m}^{3}\right) \times\left(1 \mathrm{~min} / 3000 \mathrm{ft}^{3}\right)$ $=5.31 \mathrm{E}+3 \mathrm{mg} / \mathrm{m}^{3}$

Thus the benzene concentration in the building air is less than the IDLH $\left(9.57 \mathrm{E}+3 \mathrm{mg} / \mathrm{m}^{3}\right)$ value for benzene and below 25 percent of the LFL (1.04E $+4 \mathrm{mg} / \mathrm{m}^{3}$ ) (Ref. 19). The duration of benzene release, shown in Table 3 , is conservative because it assumes that the benzene release into the stripper building occurs at the start of the stripping operation. The onsite concentration and the concentration inside the stripper building is less than the IDLH value but the release lasts longer than allowed by the IDLH guideline as shown in Figure 4. The ICR for an onsite individual and an individual inside the stripper building is below and equal to the Low Hazard criteria, respectively as shown in Figure 5.

Mitigation Mitigation measures for this event include:

- Administrative controls are in place which require evacuation of the Stripper Building on loss of building exhaust, a sign-in in the control room to enter the building with normal ventilation, and Health Protection coverage as necessary for entry when there is no ventilation.

- Ventilation-fan-failed alarm lights at entry door

4.5 Benzene/1-Butanol Deflagration in Feed Tank 
Background Flammable vapors can accumulate in the Feed Tank during the pumpdown of the tank if the inert blanket in the tank is not maintained. Should an ignition source be present, a fire can occur due to air inleakage that provides a source of oxygen. A similar accident has already been analyzed in the draft ITP Addendum (accident 3.3.1.2) to the Tank Farm SAR (Ref. 3).

Initiators The inert blanket in the tank may be lost if the nitrogen blanketing system does not maintain the nitrogen pressure as the tank is pumped down. The nitrogen blanket may also be lost if the tank is opened for inspection. This inspection will be allowed only after the tank atmosphere has been verified to have a flammable vapor (benzene and $\mathrm{BuOH}$ ) concentration of less than $10 \%$ of the LFL. After the inspection, the oxygen concentration will be restored to within requirements.

Frequency One of the initiating event for this accident is the periodic pumpdown of the tank. The draft ITP Addendum gives a frequency of 9 times/yr for this initiating event (Ref. 3). The estimated frequency of pumpdown during the simulant runs would be 30 times $/ 3$ month (WME estimate). Therefore, the frequency for this event is $6.8 \mathrm{E}-4 / \mathrm{yr}$ (Ref. 3) or 5.7E-5/month during periodic pump down.

The frequency for this accident if 4 inspections are performed could be $4.0 \mathrm{E}-2 / \mathrm{yr}$. This assumes that sufficient oxygen leaks during inspection.

Consequences There are no radiological consequences to this event, because no radioactive material is involved. The weld history and the acceptance testing of the Feed Tank indicates that it is not a coded pressure vessel. Therefore, the Feed Tank could fail during a potential benzene deflagration. The release of benzene from the rupture of the Feed Tank would be instantaneous. The toxic chemical hazard methodology (Ref. 20) allows the use of peak 15 minute average concentration for facility, onsite, and offsite comparison with the guidelines. The peak 15 minute average concentration can be used except for those substances that may cause immediate irritation when exposures are short. Benzene does not cause immediate irritation when exposures are short. Exposures of $3000 \mathrm{ppm}$ up to 30 minutes would not cause toxic effects in humans (Ref. 17). The facility, onsite, and offsite concentration of benzene, released during deflagration from the vapor phase and in the entrained liquid, is significantly lower than the amount released during accident 4.2 as shown in Tables 2 and 7 and Appendix A.

The facility benzene concentration from an instantaneous release ( 1 sec release time) during deflagration is also compared against the benzene exposure during normal operation. The benzene exposure ( $65.5 \mathrm{mg}$ of benzene) to a facility individual during benzene 
deflagration would be about 6 times the one working day exposure (10.7 $\mathrm{mg}$ of benzene) during normal operation (Appendix A).

The failure of the Feed Tank from a deflagration could impact the nearby Tanks 48,49 , and 50 (Tank Farm facilities) by disabling their ventilation systems. The frequency of $7.9 \mathrm{E}-8 / \mathrm{hr}$, for the failure of the Feed Tank during deflagration, will be the initiator for disabling the ventilation on Tanks 48,49 , or 50 and it is order of magnitude lower than the lowest initiator frequency of $1.0 \mathrm{E}-6 / \mathrm{hr}$ in the Tank Farm SAR (Ref. 23).

The calculated fatality frequency of $1.1 \mathrm{E}-4 / \mathrm{yr}$, from the failure of the Feed Tank, is comparable to the chemical process industry guideline of less than 1.0E-4/yr. This calculation assumes a two-month duration for the simulant runs with benzene in the Feed Tank (Ref. 27), and takes no credit for the absence of an individual at the location of the missile impact.

The pressure from $\mathrm{BuOH}$ deflagration is below the benzene deflagration pressure (Ref. 35 ). The volatility of the $\mathrm{BuOH}$ is significantly lower than the benzene. The vapor phase benzene concentration contributes about $99 \%$ (Appendix A) to the total amount of the benzene released during the deflagration. Therefore, consequences of the $\mathrm{BuOH}$ deflagration are bounded by benzene deflagration consequences.

Mitigation. Mitigation measures for this event include:

- Electrical equipment classified for use in areas where flammable vapors can exist

- Before initial tank filling, purging with nitrogen to maintain oxygen concentration below the minimum concentration for combustion. The oxygen concentration is verified using an oxygen monitor after the purge is completed

- Flame arrestor on the vacuum relief of the Feed Tank and on the conservation vent of the Flush Tank

- Administrative controls to purge the tank if nitrogen pressure is lost

- Nitrogen blanket maintained by a tank pressure regulator

- Monitor oxygen concentration in the Feed Tank every shift

4.6 Benzene Deflagration/Release During the Column Cleaning 
Background The purpose of the stripping column is to remove benzene from the filtrate. Oxalic acid is used for column cleaning if there is scaling or pluggage. Benzene could be chemically released during the column cleaning, assuming that tetraphenylborate is adsorbed on the packing. The stripper column exhaust gases mix with the building exhaust air as shown in Figure 2.14 of Reference 3. If the stripper building ventilation blower is not running, then an interlock closes the valve in the exhaust line between the column and the stack. If the ventilation stops and benzene keeps accumulating in the stack, then an ignition source can cause deflagration of benzene. This accident has already been analyzed in the draft ITP Addendum to the Tank Farm SAR (Ref. 3).

Initiators Benzene concentration in the offgas from a stripping column can exceed the lower flammability limit (LFL) if the building ventilation fails during cleaning and the valve interlock fails. Also needed is a source of ignition. Benzene also can be released to the stripper building through the pressure relief valve.

Frequency The frequency for this event is $1.1 \mathrm{E}-4 / \mathrm{yr}$ (Ref. 3) or $9.2 \mathrm{E}-6 /$ month.

Consequences There are no radiological consequences to this event, because no radioactive material is involved. The onsite and offsite concentration of benzene released through the stack, shown in Tables 3 and 4, is below the IDLH and 0.01 IDLH value, respectively. The pressure rise caused by a benzene deflagration in the exhaust stack of the stripper building would not rupture the stack (Ref. 11) and hence, there would not be any damage to outside equipment or personnel. The concentration of benzene released in the stripper building, through the pressure relief valve, is $1.33 \mathrm{E}+3 \mathrm{mg} / \mathrm{m}^{3}$ which also is less than the IDLH value and below the 25 percent of LFL. The ICR for an onsite individual and an individual inside the stripper building is below the Low Hazard criteria in FSAM (Figure 5).

Mitigation Mitigation measures for this event include:

- Administrative controls are in place to require an initial nitrogen purge of the stripper column before cleaning that column with oxalic acid and to require building ventilation be operating to start and to continue oxalic acid cleaning

- $\quad$ Stripper exhaust stack height of $90 \mathrm{ft}$

- Building ventilation failure alarm

- Valve interlock in the exhaust line between the column and the stack 
- No known ignition source because equipment is electrically classified for use ina flammable environment (no credit taken).

4.7 Filter Cell Deflagration and Fire

Background The ITP filter and associated piping are located inside a shielded area of the filter building, called the filter cell. This area is air ventilated at about $1,000 \mathrm{cfm}$ by an exhauster through a single stage of HEPA filters. There are eight HEPA filters in this stage to accommodate the volume of ventilation air.

During filtration operations precipitate slurry is pumped from feed tank through the ITP filter at a rate of about $500 \mathrm{gpm}$. The filtrate goes to a benzene stripping column via a seal tank; the concentrated precipitate slurry returns to feed tank.

The floor of the filter cell contains a sump with a liquid level detector and a sump jet. An interlock to the liquid detector shuts down the precipitate slurry pump if a liquid leak is detected in the sump. This slurry pump also is shut down by another interlock if the cell ventilation fails. If leaks are detected or suspected, the cell has a water spray system to wash any leakage into the sump for jetting back into the process. This benzene deflagration and solids fire accident has already been analyzed in the draft ITP Addendum to the Tank Farm SAR (Ref. 3).

Initiators A release of precipitate slurry into the filter cell would release benzene vapors into the cell air. Under the most likely conditions, the vapor would remain below the LFL with the ventilation system operating.

A release that occurs in the cell when the ventilation is off releases the benzene present in the slurry at the time of the spill. For small or slow spills, the time to reach the LFL in the cell is very large, allowing time to mitigate the hazards from the spill. However, for a spill of 2,000 gal or more the initial benzene content in the spill brings the vapor concentration close to the LFL (Ref 3 ). Because of this, filtration operations are terminated (by an interlock) if ventilation stops in the filter cell.

Periodic inspection of each cell will occur prior to each filter and stripper column test. The planned testing and inspection program are judged adequate to prevent solids accumulation in the cell.

There are no known sources of ignition in the filter cell.

Frequency The frequency of this accident is estimated to be $2.2 \mathrm{E}-6 / \mathrm{yr}$ (Ref. 3) or 1.8E-7/month. 
Consequences There would not be an immediate fire hazard from the leak for two reasons. First, the ventilation rate in the cell would dilute the benzene vapors well below the lower flammability limit. Second, the leaked slurry would have to dry before becoming combustible.

There are no radiological consequences and the only chemical consequence would be the release of some unburnt KTPB. The amount of KTPB released in this accident would be significantly less than the amount released in accident 4.2.

Mitigation Mitigation measures for this accident include:

- A minimum flow of ventilation air through the filter cell is required for filtration operations. Should this fail, filtration must be shut down.

- The precipitate slurry pump is shut down automatically by an interlock if a liquid leak is detected in the cell sump.

- Periodic inspections of the cell are made to detect any accumulation of solids on the piping connections or floor. Should such be detected, no further filtration is allowed until the cell is adequately cleaned and free of these solids.

- Water sprays in the cell can be used to keep any sump contents wet and prevent drying.

4.8 Feed Solution Spill Due to the Over Pressurization of the Transfer Hose

Background The spill of Feed Tank solution due to over pressurization of the transfer hose is evaluated because this is the worst possible accident scenario for the hose failure. Over pressurization of the chemical transfer hose from the Feed Tank to Tank 48 could result in personnel injury from the spilled material or a chemical spill reaching the nearby creek/stream. The chemical transfer hose to be utilized during the transfer has been hydrotested to $200 \mathrm{psig}$, which is $\sim 150 \%$ of what the diaphragm/filtrate pump is capable of providing (Ref. 10).

Initiators Feed solution can spill if the transfer hose ruptures.

Frequency The probability of a hose rupture is $4.4 \mathrm{E}-5$ (Ref. 14), and the frequency of transfer is 5 times/3 months (estimate from WME). Therefore, the frequency for this event is $7.3 \mathrm{E}-5 / \mathrm{month}$.

Consequences There are no radiological consequences to this event, because no radioactive material is involved. The worst 
consequences of this accident would be the release of the entire 12,000 gallons of solution in the Feed Tank. The magnitude of facility, onsite, and offsite concentrations of chemicals, from a release of this magnitude (12,000 gallons), would be similar to accident 4.2 even though the spill is not confined to the dike. The surface area of the spill could be greater than the diked area used in this accident, but the rate of benzene release from the solution would be controlled by the rate of solution spill. The amount of benzene present in 12,000 gallons of solution is released in $73 \mathrm{sec}$. (Table 3), and it would take 60 minutes to spill the entire 12,000 gallons outside the dike because of the pump capacity of $200 \mathrm{gpm}$. Therefore, the surface area used in this calculation is conservative.

Mitigation Mitigation measures include:

- Hydrotesting of the transfer hose up to 200 psig.

- $\quad$ Pumps capable of providing up to 135 psig.

- Local storm sewers diverted to the H-Area Retention Basin prior to transfer.

4.9 Solids Fire in Tank 50

Background Dissolved salts of cesium and potassium are present in most waste tanks. If mixed with a solution of $\mathrm{NaTPB}, \mathrm{Cs}^{+}$and $\mathrm{K}+$ ions react to form KTPB and CSTPB (XTPB). Feed solution containing NaTPB and insoluble salt of KTPB could be inadvertently transferred to Tank 50. These solids present a fire hazard inside affected waste tanks. This accident has already been analyzed in the draft ITP Addendum to the Tank Farm SAR (Ref. 3).

Initiators A transfer error in which the transfer hose from feed solution tank is connected to Tank 50 . Transfer error must be accompanied by 1) a failure to detect the error before a hazardous quantity is transferred, 2) an ignition source and 3) the requirements for the precipitate (insoluble salts) to dry out in order to arrive at the top event, solids fire in Tank 50 .

Frequency The probability of connecting the transfer hose to a wrong tank is $1.0 \mathrm{E}-2$ (Ref. 12), the error not detected is $2.0 \mathrm{E}-1$ (Ref. 12), and the frequency of transfer is 5 times/ 3 months (estimate from WME). The probability of having an ignition source is $1.0 \mathrm{E}-1$ (Ref. 3 ) and no credit is taken for the precipitate to dry out (Ref. 3). Therefore, the frequency for this event is $3.2 \mathrm{E}-4 /$ month.

Consequences The worst transfer error would be 12,000 gallons containing 0.04 moles/l of NaTPB and approximately 1 wt \% of KTPB. KTPB from feed solution tank is non-radioactive, but it could adsorb 
some amount of radioactivity from the solution in Tank 50. XTPB that forms in Tank 50 will be radioactive.

XTPB floats on the surface of most tanks in which it might form, and some of the XTPB can therefore be expected to be deposited on tank walls where it can dry sufficiently to be ignited. The source term for this accident has already been calculated in the draft ITP Addendum (Ref. 3). It does not include the contribution of radionuclides that could be adsorbed on the non-radioactive precipitate because of lack of data.

The atmospheric source term estimate is believed to be conservative by perhaps one or more orders of magnitude for the following reasons, the effects of which cannot be quantified at this time:

- Ignition might result in only partial combustion. Fires ignited on test plates did not propagate for thin films (approximately 0.1 inch). In thicker films, fire propagation was less than complete and tended to be mainly vertical.

- $\quad$ Smoke from burning XTPB tends to agglomerate into long stringy pieces that adhere to surfaces and will likely not remain dispersed in a low-velocity air stream.

The tank at risk (Tank 50) has an air atmosphere with no provisions for inerting. It would therefore be difficult to extinguish a solids fire, once ignited. In addition, it is likely the exhaust HEPA filter on the affected tank would be rendered ineffective due to solids overloading.

The radiological consequences are contained in Table 5 (Ref. 3). The risk of 3.6E-6 rem/yr from this accident to an offsite individual is lower than the Waste Tank Filter Fire accident risk of 3.5E-5 rem/yr in the Tank Farm SAR(Ref. 23)

Mitigation Mitigation measures for this event include:

- Administrative and procedural controls on transfer

- No nozzle on Tank 50 (to prevent inadvertent transfer from Feed Tank)

\subsection{Corrosive Flush Solution Added to Tank 50 or Tank 48}

Background Corrosive solution could be sent to Tank 50 or Tank 48 if sampling of the ITP Flush Tank is not performed to ensure that the flush solution has a $\mathrm{pH}>12$. Transfer of material with $\mathrm{pH}<12$ would violate corrosion controls (Ref. 8,9). Normally the flush solution will be transferred to Tank 50 but it could be transferred to Tank 48 depending on the benzene concentration of the flush solution. 
Initiators The common initiator for Tank 50 or Tank 48 would be the lack of $\mathrm{pH}$ analysis of Flush Tank solution or no corrective measures taken whenever $\mathrm{pH}$ of solution is less than 12.

Frequency The Flush Tank solution will be transferred 30 times/3 months (estimate from WME). The probability of not analyzing the solution for $\mathrm{pH}$ or for not taking mitigation measures is $1 \mathrm{E}-2$ (Ref. 12). The estimated frequency of transferring corrosive flush solution to Tank 50 or Tank 48 is $1.0 \mathrm{E}-1 /$ month.

Consequences The flush solution, after neutralization, will be transferred to Tank 50, which contains an average volume of 300,000 gallons at a pH of 14.0. If the maximum volume of 15,000 gallons of oxalic acid ( 4 weight \%), that could be used during the entire filter/stripper test runs and quiet time runs program, is added to Tank 50 , then the $\mathrm{pH}$ of the solution would decrease from 14.0 to 13.96 . In order to maintain a $\mathrm{pH}$ of 12 or higher, the minimum volume of waste that must be in Tank 48 or 50 to accept 15,000 gallons of 4 weight \% oxalic acid is 18,000 gallons at a pH of 14.0 . The surveillance of the tank volume will ensure that both the tanks have a minimum volume of 50,000 gallons (Ref. 28). Therefore, the addition of 15,000 gallons of 4 weight \% oxalic acid to Tanks 50 or 48 would have no consequences (corrosion).

Mitigation Mitigation measures for this event include:

- Analyze the contents of Flush Tank before each transfer

- Administrative and procedural controls on transfer

\subsection{Deflagration in Filtrate Hold Tank}

Background The Filtrate Hold Tanks (FHT) receive filtrate from the stripper columns. The solution usually has a low concentration of benzene. The benzene in the solution was removed by the stripper column. Should the benzene concentration be abnormally high, the vapor is not flammable because the inert blanket gas (nitrogen) does not contain enough oxygen for benzene/ combustion. If the inert atmosphere is lost and the benzene/ concentration is abnormally high $(>L F L)$, then an ignition source can cause a deflagration of benzene. The benzene deflagration accident has already been analyzed in the draft ITP Addendum to the Tank Farm SAR (Ref. 3).

The TBP could produce $\mathrm{BuOH}$ by hydrolysis if filtrate is left in the FHT for extended periods. The concentration of flammables in the vapor phase will not exceed LFL even if all the TBP hydrolyzes completely to $\mathrm{BuOH}$ as long as the benzene, methanol, and isopropanol concentration is $2.5 \mathrm{mg} / \mathrm{l}, 400 \mathrm{mg} / \mathrm{l}$, and $430 \mathrm{mg} / \mathrm{l}$, respectively (Ref. 
44). This calculation assumes a maximum fill level of 12,000 gallons in the FHT.

Initiators There are two possible ways that the benzene concentration could become abnormally high. Oxalic acid used to clean the stripper columns could be inadvertently added to a FHT, causing a chemical reaction which would increase the benzene evolution rate. The second way involves inefficient stripper column operation. For example, the flow rate of the stripping gas (nitrogen) could be insufficient because the setpoint is too low on the controls. (In this case, high benzene concentrations in the filtrate should be detected by the gas chromatographic analysis done on filtrate. Solutions exceeding the benzene limit are recycled through the Feed Tank to the column.)

The inert gas blanket in the FHT may be lost if the nitrogen control valve does not open to maintain the nitrogen pressure as the tank is pumped down. Air could be drawn into the tank through the conservation vent or the overflow line (Ref. 3).

Frequency The frequency is calculated at $1.75 \mathrm{E}-09 / \mathrm{hr}(1.5 \mathrm{E}-05 / \mathrm{yr})$ for one FHT as shown in Figure 6 . The frequency for both the FHTs is $3.1 \mathrm{E}-05 / \mathrm{yr}$ or $2.6 \mathrm{E}-6 /$ month.

Consequences There are no radiological consequences. The FHT is not expected to rupture during the deflagration (Ref. 3). However, if it did the amount of benzene/BuOH (present in the entrained liquid) released would be significantly lower than the amount released during accident 4.2 .

Mitigation Vapor deflagration in the filtrate hold tanks are prevented by eliminating two causes of fire, fuel and oxygen. The filtrate is held in a filtrate hold tank and then transferred to Feed Tank. As long as the stripping column is efficient in removing benzene from the solution, the benzene hazard is mitigated. Should the columns become inefficient for any reason, the inert nitrogen blanket in the filtrate hold tank maintains safe conditions until action is taken, e.g., to restore efficient operation and recycle the filtrate.

Temporary loss of the inert blanket would have no real consequences as long as the columns are stripping benzene as designed. The nitrogen supply system on these tanks is designed to maintain a positive pressure in the tank vapor space. If there are leaks in the tank, nitrogen would leak out rather than air leaking in. As the tanks fill from the stripper columns, tank vapors are forced out of the tank. The likely time for air inleakage would be when the tank contents are pumped out. 
An inert atmosphere will be established (in these tanks before any filtration is begun) by purging the tanks with nitrogen. The atmospheres will be verified as inert (i.e., less than $3.6 \%$ oxygen by volume) by monitoring the tank exhaust for oxygen content during purging. The inert atmosphere will be continuously monitored during the FHT pumpdown.

After the filtrations begin, the blankets will be continuously maintained with positive nitrogen pressures. Should the pressure in a tank vapor space be lost ( $p<0$ psig), alarms are received. At that time, the purging and verification will be repeated by administrative controls.

4.12 Flush Solution (Containing Oxalic Acid) Inadvertently Added to Feed Tank

Background Flush solution containing about 4 weight \% oxalic acid will be used for cleaning the filters and stripper columns. This solution could be inadvertently added to feed tank. Oxalic acid reacts with Na/KTPB to produce benzene. Workers can be exposed to benzene released through the conservation vent on the feed tank.

Initiators The most likely initiator for this event is the inadvertent opening of the valve to the feed tank during cleaning.

Frequency The probability of leaving the valve open is $1.0 \mathrm{E}-2$ (Ref. 12) and of the valve error not detected is $2.0 \mathrm{E}-1$ (Ref. 12). The probability of not having spectacle flange in the line is $1.0 \mathrm{E}-2$ (Ref. 12). The frequency of using the flush solution is 30 times $/ 3$ month (estimate from WME). Therefore, the frequency for this event is $2.0 \mathrm{E}$ $4 /$ month.

Consequences The onsite and offsite concentration of benzene released through the conservation vent shown in Table 2 is below the IDLH and 0.01 IDLH value, respectively. The facility concentration of benzene is below the 0.1 IDLH value as shown in Table 7. The duration of benzene release is below the IDLH guideline (Figure 4) and the ICR value for an onsite individual is below the Low Hazard criteria in FSAM (Figure 5)

Mitigation Mitigation measures for this event include:

- Administrative and procedural controls on transfer

- Spectacle flange in the line

4.13 Tank 50 Deflagration

This accident is analyzed in Reference 8. 
4.14 Criticality in Tank 50

This accident is analyzed in Reference 8.

4.15 Deflagration in TBP Feed Tank

The addition of a wrong chemical (acid or base) or a backflow of filtrate into the TBP feed tank could generate flammable vapors of 1 butanol. Should an ignition source be present, a 1-butanol deflagration can occur.

The flow test of the TBP Injection system showed that the backflow of the filtrate through the feed pump is physically impossible due to pump configuration. There will be a single addition of up to 55 gallons of TBP in the TBP feed tank but no more than 25 gallons will be injected into the filtrate during the entire simulant runs. TBP feed tank is the only cold chemical tank in the Stripper Building which requires chemical additions. Therefore, the addition of wrong chemical to the TBP already in the tank is physically impossible.

4.16 Transfer of Filtrate to Tank 50

This transfer is analyzed in Reference 8.

4.17 Transfer of 'Information Only' Simulant Solution, Inhibited Water, and Spent Simulant Solution to Tank 48

The composition of 'Information Only' simulant solution, inhibited water, and spent simulant solution are contained in Tables 10, 11, and 12 , respectively. The 'Information Only' simulant solution contains salt solution, benzene (up to $300 \mathrm{ppm}$ ), TBP (up to 10 gallons) and $\mathrm{BuOH}$ (decomposition product of TBP). The transfer of 'Information Only' simulant solution has already been completed. The inhibited water contains caustic and benzene (up to $50 \mathrm{ppm}$ ). The spent simulant solution contains salt solution, STPB, ST, benzene (up to $15 \mathrm{ppm}$ ), methanol (up to $308 \mathrm{ppm}$ ), isopropanol (up to 331 $\mathrm{ppm}$ ), TBP (up to 25 gallons), and $\mathrm{BuOH}$ (decomposition product of TBP).

The hazards to Tank 48 from the 'Information Only' simulant solution, inhibited water, and spent simulant solution are the flammables benzene, alcohols, and TBP.

\section{Flammables in 'Information Only' Simulant Solution}

Moles of benzene in simulant solution $=300 / 1.0 \mathrm{E}+6 \times 12,000 \mathrm{gal}$ $\times 3.78 \mathrm{l} / \mathrm{gal} \times 0.88 \mathrm{~g} / \mathrm{cc}$ $\times 1000 \mathrm{cc} / \mathrm{l} \times \mathrm{g}$ mole $/ 78 \mathrm{~g}$ $=153.5 \mathrm{~g}$ moles 
Average temperature in Tank 48 (Ref. 36$)=26^{\circ} \mathrm{C}$

Assume all benzene goes into vapor phase in Tank 48 .

Volume occupied by 1 mole of benzene at $26^{\circ} \mathrm{C}=22.4 \mathrm{l} / \mathrm{g}$ mole $\times 299.15 \mathrm{~K} / 273.15 \mathrm{~K}$ $=24.5 \mathrm{l} / \mathrm{g} \mathrm{mole}$

Volume occupied by $153.5 \mathrm{~g}$ moles of benzene $=153.5 \mathrm{~g}$ mole $\times 24.5 \mathrm{l} / \mathrm{g}$ mole $=3761.41$

Liquid in Tank 48 (Ref. 38) = 62.1 inch $\times 3510 \mathrm{gal} / \mathrm{inch}$ $=217,971 \mathrm{gal}$

Vapor volume in Tank $48=1.39 \mathrm{E}+6 \mathrm{gal}-217,971 \mathrm{gal}$ $=1.17 \mathrm{E}+6 \mathrm{gal} \times 3.78 \mathrm{l} / \mathrm{gal}$ $=4.42 \mathrm{E}+6 \mathrm{I}$

Benzene vol. \% in Tank $48=3761.4 \mid / 4.42 \mathrm{E}+6 \mathrm{I} \times 100$ $=8.5 \mathrm{E}-2 \%$

LFL of Benzene $=1.3 \%($ Volume $\%)$

$\%$ of LFL due to Benzene $=8.5 \mathrm{E}-2 / 1.3 \times 100=6.54 \%$

Moles of TBP in simulant solution $=10 \mathrm{gal} \times 3.78 \mathrm{l} / \mathrm{gal} \times 1000 \mathrm{cc} / \mathrm{l}$ $\times 1.0 \mathrm{~g} / \mathrm{l} \times \mathrm{g}$ mole $/ 266 \mathrm{~g}$ $=142.1 \mathrm{~g}$ moles.

1 mole of TBP decomposes to 3 moles of $\mathrm{BuOH}$. Since TBP has negligible pressure at the operating temperatures, it is assumed that all of it has decomposed to $\mathrm{BuOH}$.

Moles of $\mathrm{BuOH}=142.1 \mathrm{~g}$ moles of TBP $\times \frac{3 \text { moles of } \mathrm{BuOH}}{1 \text { mole of } \mathrm{TBP}}$ $=426.3 \mathrm{~g}$ moles of $\mathrm{BuOH}$

Assume all BuOH goes into vapor phase in Tank 48.

Volume occupied by $426.3 \mathrm{~g}$ moles of $\mathrm{BuOH}=24.5 \mathrm{l} / \mathrm{g}$ mole $\times 426.3 \mathrm{~g}$ mole $=10,444.71$

BuOH vol. \% in Tank $48=10,444.7|/ 4.42 \mathrm{E}+6| \times 100=2.36 \mathrm{E}-1 \%$ 
$\mathrm{LFL}$ of $\mathrm{BuOH}=1.4 \%$ (Volume \%)

$\%$ of $\mathrm{LFL}$ due to $\mathrm{BuOH}=2.36 \mathrm{E}-1 / 1.4 \times 100=16.9 \%$.

$\%$ of $L F L$ due to benzene and $\mathrm{BuOH}=23.4 \%$.

Flammable in Inhibited Water

Moles of benzene in Inhibited Water $=50 / 1.0 \mathrm{E}+6$

$\times 5,000 \mathrm{gal} /$ transfer

$\times 3.78 \mathrm{~V} / \mathrm{gal} \times 0.88 \mathrm{~g} / \mathrm{cc}$

$\times 1000 \mathrm{cc} / \mathrm{g} \times \mathrm{g} \mathrm{mole} / 78 \mathrm{~g}$

$=10.7 \mathrm{~g} \mathrm{moles} /$ transfer

Number of transfers $=4.0$

$\therefore$ Total moles of benzene in inhibited water transferred to Tank 48

$$
\begin{aligned}
& =10.7 \mathrm{~g} \text { mole/transfer } \\
& \times 4 \text { transfer } \\
& =42.8 \mathrm{~g} \text { moles }
\end{aligned}
$$

Assume all benzene goes into vapor phase in Tank 48 .

Volume occupied by $42.8 \mathrm{~g}$ moles of benzene $=24.5 \mathrm{l} / \mathrm{g}$ mole $\times 42.8 \mathrm{~g}$ mole

$$
=1048.61
$$

Volume of vapor space after transfers (Ref. 45$)=3.8 \mathrm{E}+6 \mathrm{I}$

Benzene vol. \% Tank $48=1048.6 \mathrm{I} / 3.8 \mathrm{E}+6 \mathrm{I} \times 100=2.8 \mathrm{E}-2 \%$

$\%$ of LFL due to Benzene $=2.8 \mathrm{E}-2 / 1.3 \times 100=2.1 \%$

Flammables in Spent Simulant Solution

There will be a maximum of two transfers of 12,000 gallons of spent simulant solution of composition shown in Table 12. The calculations, under the most conservative assumptions, show that only $7.3 \%$ of the composite LFL can be reached in Tank 48 without any ventilation. These calculations include the earlier transfer of 'Information Only' simulant solution into Tank 48 (Ref. 45).

Conditions in Tank 48 Before Transfer

Benzene concentration in Tank 48 (Ref. 37) exhaust @ ventilation rate of $340 \mathrm{cfm}=1.4 \mathrm{ppm}$

Benzene generation in Tank $48=1.4 / 1.0 \mathrm{E}+6 \times 340 \mathrm{cu}$. feet $/ \mathrm{min}$ (1/0.03532 cu feet $/ \mathrm{min}$ )

$$
=1.35 \mathrm{E}-2 \mathrm{l} / \mathrm{min}
$$


Benzene vol. \% in Tank $48=1.35 \mathrm{E}-2 \mathrm{l} / \mathrm{min} \times 100 / 4.42 \mathrm{E}+6 \mathrm{I}$

$=3.05 \mathrm{E}-7 \% / \mathrm{min}$

$\%$ of LFL due to benzene $=3.05 \mathrm{E}-7 \% \times 100 / 1.3 \% \mathrm{~min}$ $=2.3 \mathrm{E}-5 \% / \mathrm{min}$

To have benzene concentration equivalent to $1 \%$ of $L F L$, we will need a ventilation loss of $2.3 \mathrm{E}+5$ min or 91 days. Therefore, benzene generation rate in Tank 48 is insignificant.

\section{Conditions in Tank 48 After the Transfer}

$\%$ of LFL due to spent simulant solution and inhibited water (4 transfers) addition $=7.3 \%+2.1 \%=9.4 \%$

The flammable concentration in the vapor phase is about $9 \%$ of LFL in the vapor space of Tank 48 from all transfers with no ventilation working.

\section{Conclusion}

The concentration of flammables in vapor phase from all the solutions ('Information Only' simulant solution, 4 transfers of inhibited water solution and 2 transfers of spent simulant solution) transferred to Tank 48 and the existing concentration of flammables in Tank 48 will be about $9 \%$ of $L F L$ with no ventilation running.

Considering the possibility of benzene/BuOH stratification in the vapor space of Tank 48 and of possible disturbance during the addition, continuously monitor the \%LFL value during the transfer and be prepared to stop the transfer should the \%LFL increase significantly.

\section{Combustibility Potential of TBP in Tank 48}

The laboratory tests and solubility data indicate that at least 90 gallons of TBP are required to form a complete layer on the surface of salt solution in a Type III waste tank. Isolated pools of TBP could not be ignited with a butane flame when the bulk solution was heated to 70 degree Celsius. Therefore, 25 gallons of TBP will be insufficient to form a layer covering the entire surface of the solution and as such is not expected to be combustible (Ref. 45).

\section{Criticality Potential In Tank 48}

The fissile material present in Tank 48, either adsorbed on the sodium tittanate or present in the supernate, is insufficient to exceed the evaluated safe loading on the sodium titanate. Any addition of 
sodium titanate to this tank will only increase the margin of safety as long as no additional fissile material enters the tank (Ref. 47)

Experimental studies have shown that the addition of TBP into the ITP process will not affect the uranium solubility for alkaline solutions. Uranium was not extracted from the salt solution into a floating TBP phase. Literature data supports the conclusion that plutonium behavior in this case is the same as uranium. Even though a TBP concentration range of 22 to $508 \mathrm{ppm}$ was used for testing, any concentration of TBP will have the same results because TBP is sparingly soluble in alkaline solutions (about $1 \mathrm{ppm}$ ). Therefore, TBP will not affect the chemical behavior of uranium and plutonium in alkaline salt solutions and does not create any criticality risk (Ref. 43).

4.18 Releases During Normal Operations

Stack Releases

The maximum benzene concentration is at 100 meters for a 50 feet high stack release (Ref. 24). The estimated highest maximum 8-hour average ground level benzene concentration is below 0.5 ppm (Ref. 26).

\section{Feed Tank Releases}

The filtrate from the FHT and/or the salt solution from the tanker truck is pumped to the Feed Tank 50 times during the Test Runs (Ref. 40). The time to transfer filtrate from the FHT or the salt solution from the tanker truck to the Feed Tank is about 343 minutes ( $35 \mathrm{gpm}$ )(Ref. 27). Therefore, the release of benzene from the Feed Tank will last 343 minutes each time the filtrate or the salt solution is transferred to the Feed Tank (Ref. 27). The volume of filtrate or salt solution transferred during simulant runs is 12,000 gallons. The 8 -hour and 1 -hour average maximum concentration of benzene and 1-butanol (Ref. 24,30 ) at different locations in the ITP facility are shown in Tables 8 and 9 , respectively.

The 1-hour average maximum concentration of benzene and at the Filter/Stripper building $(241-96 \mathrm{H})$ is 102 times, 3 times, and 0.7 times the short term exposure limit (STEL) (15 minute limit) of $5 \mathrm{ppm}$ during filtrate transfer, pump operation, and thermal cycling, respectively (Table 9). The 1-hour average maximum concentration of benzene is below STEL for distances greater than $\mathbf{3 0}$ meters during all normal operations.

The 8-hour average maximum concentration of benzene at different locations in the ITP facility from the Feed Tank are shown in Table 8 (Ref. 24,30). The maximum concentration of benzene is at or below 
the action level $(0.5 \mathrm{ppm})$ except at building $241-96 \mathrm{H}$ where it is 128 times, 10, times, and 1.4 times the action level during the filtrate transfer, pump operation, and thermal cycling, respectively.

During the dissolution of benzene in the salt solution, evaporation of benzene within the Feed Tank will increase the pressure in the tank. Therefore, the benzene vapors will be released in small amounts from the conservation vent over a period of hours until the desired solubility is reached in the Feed Tank. This instantaneous benzene release would occur 3 times every 15 minutes (Ref. 40). The Occupational Safety and Health Administration (OSHA) STEL (5 ppm or $16 \mathrm{mg} / \mathrm{m}^{3}$ ) guideline is a 15 minute average concentration. Therefore, if the release is averaged over a 15 minute period, the benzene release rate would be $2.36 \mathrm{~g} / \mathrm{sec}$. This 15 minute average benzene concentration is about $70 \%$ of the concentration during filtrate transfer ( $3.29 \mathrm{~g} / \mathrm{sec}$ of benzene) but the instantaneous benzene concentration would be significantly higher.

It is recommended that the access to the building $241-96 \mathrm{H}$ be controlled and limited during the entire testing program. The benzene concentrations must be monitored at building $241-96 \mathrm{H}$ and at other locations (up to 30 meters from the Feed Tank) to determine the areas where benzene concentration is above the STEL of $5 \mathrm{ppm}$ during filtrate transfer and benzene dissolution. If the benzene concentration is above the STEL during filtrate transfer or during benzene dissolution, then the access to those areas will be controlled.

4.19 Damage to the Permanent ITP and Tank Farm Facilities

Damage to the permanent ITP facilities result from an error in operation (e.g. exceeding the maximum pressure differential across the filter media), modifications to the equipment/facility in order to perform the filter/stripper runs and quiet time runs program, or improper storage of equipment after the completion of testing. The Mott filter is the piece of equipment most vulnerable to damage and is the object of most of the items listed below. There are no onsite or offsite chemical dose consequences from the damage to the permanent ITP facilities.

\section{Operational Errors/Problems:}

Siphon potential exists from the Feed Tank through the filter return downcomer. However, the consequences and mitigations of a siphon accident will be similar to a spill as discussed in accidents 4.1 and/or 4.2. There are no other downcomers in the Feed Tank and there are no downcomers in the Flush Tank.

The Feed Tank and the FHT could be damaged during the runs as indicated in accidents 4.5 and 4.11 , respectively. 
Operational errors, that could result in damage to the permanent ITP facilities include:

- Exceeding the design pressure drop across the filter media could rupture the filter tubes or cause irreversible plugging of the filter media. Tube rupture could occur with either slurry or water; complete media plugging is possible with slurry or unfiltered well water. Either tube rupture or media plugging could occur as the result of accidentally over-restricting the tube side flow downstream of the filter or incorrect operation of the pump used to feed the filter.

- Water hammer could occur at startup.

These types of errors are unlikely because of the following controls:

- Controls/interlocks on the permanent facility and the temporary facilities have been functionally checked. These include an administrative control to ramp the filter feed pump up to the desired flow rate whenever it is started; interlocks to stop the filter feed pump on low precipitate flow, on high precipitate pressure and when filter isolation valves are closed; and an automatic control which delays the opening of the filter inlet valve when filter feed pump is started.

- The variable speed drive for the permanent filter feed pumps will be used to operate the temporary filter feed pump. This will allow use of some process interlocks in place to protect the filter.

- The pump will be started at low speed to reduce the potential for water hammer. 


\subsection{References}

1. "Preoperational Process Hazard Report In-Tank Precipitation Temporary Cold Run Facility", WSRC-PH-90-82, January 7, 1991.

2. "In-Tank Precipitation Preoperational Process Hazard Review Report", WSRC-PH-90-83, September 4, 1991.

3. "Additional Analysis for DWPF Feed Preparation by In-Tank Processing -Draft", WSRC-SA-15, Rev. 3, August, 1993.

4. "Operational Safety Requirements for In-Tank Precipitation Process Draft", WSRC-RP-90-1124, Rev. 3, August, 1993.

5. D. D. Walker, "Sample Analyses from the Full Scale In-Tank Demonstration of the Precipitation Process", DPST-83-695, July 21, 1983.

6. J. P. Wood, "In-Tank Precipitation Slurry Run-In Plan - Draft", OPS-WMH-890051, September 22, 1989.

7. "In-Tank Precipitation Simulant Run Test Plan", WER-WMH-92-0052, Rev. $11,3 / 31 / 94$.

8. T. P. Gaughan, "Transfer of Salt Solution from Tank $50 \mathrm{H}$ to Saltstone", WSRC-OX-89-15-001, Rev. 6, 5/27/94.

9. Technical Standard, Waste Tank Farms, DPSTS-241.

10. T. P. Gaughan, "Process Hazards Review Report, Transfers from the ITP Temporary Facility Flush Tank To Tank 50 - Draft", WSRC-PH-92-2, Rev. 0 (PHR-200-H-538).

11. D. D. Walker, "Consequences of a Stripper Building Stack Deflagration", IWT-LWP-90-0177, September 24, 1990.

12. A. D. Swain and H. E. Guttmann, "Handbook of Human Reliability Analysis with Emphasis on Nuclear Power Plant Applications", NUREG/CR-1278, August 1983.

13. W. S. Durant, et al., "H-Area Outside Facility Operations", DPSTSY-200-9H, August 1987.

14. "Process Equipment Reliability Data," Published by CCPS of the AIChE, 1989.

15. "Waste Management Response to Spills," 241-FH-9562.

16. "Simulant Runs Spill Cleanup Procedure," ITP-CFT(W/S)-037. 
17. National Institute for Occupational Safety and Health, NIOSH Pocket Guide to Chemical Hazards, U. S. Department of Health and Human Services, Washington, DC, June, 1990.

18. D. A. Pervis, "Safety Related Upgrades to ITP Temporary Facilities," WER-WMH-92-0185, Rev. 1, April 27, 1992.

19. National Fire Protection Association Standard, Explosion Prevention Systems/NFPA 69, Ch. 3. Combustible Concentration Reduction.

20. D. K. Craig et al., "Toxic Chemical Hazard Classification and Risk Acceptance Guidelines for Use in DOE Facilities, " WSRC-MS-92-206, Rev. 1, April, 1993

21. P. L. Fisk and W. S. Durant, "Safety Analysis 200 Area Savannah River Site Separations Area Operations Building 211-H Outside Facilities," Internal Report DPSTSA-200-10, Supp. 11, Westinghouse Savannah River Company, Savannah River Laboratory, Aiken, S. C., April 1990.

22. WSRC Facility Safety Analysis Manual, 9Q, 3-12-92.

23. "Safety Analysis-200-Area, Liquid Radioactive Waste Handling Facilities", DPSTSA-200-10, SUP 18, August 1988.

24. C. H. Hunter, "Additional Dispersion Calculations for In-Tank Precipitation (ITP) Temporary Facility", SRT-ETS-930657, June 24, 1993.

25. D. D. Walker, "Thermal Decomposition of Tetraphenylborate Solutions and Slurries", SRT-LWP-92-096, August 10,1992.

26. C. H. Hunter, "Dispersion Calculations for Non-Radiological Hazardous Chemical Emissions From the DWPF and Related Facilities (U)", WSRC-RP-90-1209, October 22, 1990.

27. D. A. Pervis, "Input Data for Safety Evaluation on Acceptance Stripper Tests (U)", WER-ITP-93-1281, Rev. 1, June 3, 1994.

28. Surveillance Round-Sheets, ITP Procedure number 241-H-1639Q, $8 / 15 / 92$.

29. J. P. Wood, "Revised Calculations for ITP Simulant Storage Tank Explosion Analysis", 2/9/90.

30. J. Stewart and C. H. Hunter, "Dispersion Modeling for Benzene Emissions from ITP Temporary Facility", SRT-ETS-930157, February 5, 1993.

31. W. E. Phillips, "Tank 48 and Tank 49 Nitrogen Purge", 
WSRC-TA-91-0005-11, 2/16/93.

32. J. P. Bibler, "Calculations Concerning and Consequences of Addition of Stripper Test Solution to Tank 48", SRT-LWP-93-026, March 30, 1993.

33. D. A. Pervis, "Estimated Impact of Butyl Alcohol Generation in Tank 48 (U)", WER-ITP-93-0389, April 30, 1993.

34. M. K. Gupta, Hazards Analysis for "Information Only" TBP Test, SRT-WAG-930107, June 16, 1993.

35. M. J. Barnes, "1-Butanol Deflagration Pressures and LFL Calculations", SRT-LWP-93-043, May 21, 1993.

36. "Waste Management Engineering Monthly Report (U)", WSRC-RP-92-78-6A, June 1992

37. D. A. Pervis, "Benzene Generation Rate in Tank 48 After Simulant Addition", WER-WMH-92-0049, September 11, 1992.

38. J. A. Pike, Tank Chemistry Report, January, 1993 (U), WER-HLE-930223, March 1, 1993

39. D. A. Pervis, ITP Operational Safety Requirements for Benzene Stripper Testing (U), WER-ITP-920285, December 31, 1992.

40. D. A. Pervis, "Routine Benzene Release Inputs for ITP Stripper Testing (U)", HLW-ITP-93-1298, October 5,1993.

41. M. K. Gupta, "Consequences of Tank 50 Deflagration", SRT-LWA-940070, Rev.1, March 21, 1994.

42. Transfer of Salt Solution from Tank $50 \mathrm{H}$ to the Saltstone Facility (U), WSRC-Ox-89-15-001, Rev. 5, 3/16/94.

43. D. T. Hobbs, "The Effects of Tri-n-Butyl Phosphate and its Degradation Products, Di-n-Butyl Phosphate and Mono-n-Butyl Phosphate on the Solubility of Actinides in Alkaline Salt Solution (U)", WSRC-TR-94-0134, Rev.1, June 6, 1994.

44. M. J. Barnes, "The Effect of Tri-N-Butyl Phosphate on the Flammability Potential of Salt Solution Transfers from the In-Tank Precipitation Facility to Saltstone (U)", WSRC-RP-94-401, April 21, 1994. 
45. M. J. Barnes and R. F. Swingle, "The Effect of Tri-N-Butyl Phosphate on Tank 48 as a Result of Salt Solution Transfers Within the In-Tank Precipitation Facility (U)", WSRC-RP-94-519, May 4, 1994.

46. M. K. Gupta, "Consequences of Tri-N-Butyl Phosphate Spill", EPD-LWS940005, May 30, 1994.

47. C. E. Bess, "Criticality Safety Basis for ITP Tank 48 Content (U)", WERWME-921077, August 24, 1992. 
Rev. 3

\section{APPENDIX A}

This appendix contains the chemical consequences for accident 4.5, Benzene/BuOH Deflagration in the Feed Tank. The chemical consequences for other accidents are contained in Reference A7 of this appendix. 
Chemical Consequences of Potential Benzene Deflagration in the Feed Tank

The Feed Tank is nitrogen-inerted before benzene is introduced. There is not enough oxygen for benzene deflagration during the dissolution of benzene in the liquid phase (salt solution). There is a possibility of air inleakage, if the nitrogen blanket system fails, during filtration. Therefore, benzene deflagration is possible during or after the filtration is started.

The chemical consequences of the benzene deflagration for the worst case are:

1. Total Benzene in Feed Tank (Ref. A1) $=20.0$ gal $=20.0 \mathrm{gal} \times 3.78 \mathrm{l} / \mathrm{gal}$ $=75.6$ liters

2. Density of Benzene at $20^{\circ} \mathrm{C}$ (Ref. A2) $=0.88 \mathrm{~g} / \mathrm{cc}$

3. Feed Tank Liquid Volume (Ref. A1) $=12,000$ gal

4. Concentration of benzene in the liquid $=173 \mathrm{mg} / \mathrm{l}$ phase before filtration (Ref. A1)

5. Benzene in liquid phase g

$$
\begin{aligned}
= & 12,000 \mathrm{gal} \times 3.78 \mathrm{l} / \mathrm{gal} \times \\
& 173 \mathrm{mg} / \mathrm{l} \times \mathrm{g} / 1000 \mathrm{mg} \times 1 / 880 \\
= & 8.92 \text { liters }
\end{aligned}
$$

6. Minimum liquid level in the Feed Tank $=1500$ gal (Ref. A1)

7. Maximum possible air in-leakage $=12,000-1500 \mathrm{gal}$

$$
=10,500 \mathrm{gal}
$$

8. The concentration of benzene in air at stoichiometric conditions (Ref. A3) $=2.7$ vol. \%

9. Volume of benzene used in the $=10,500(0.027)$ gal deflagration

$$
=283.5 \mathrm{gal}
$$

10 Volume of 1 mole of ideal gas at $273 \mathrm{~K}=22.4$ liters and $1 \mathrm{~atm}$ (Ref. A4) 
11 Volume of 1 mole of ideal gas at $25^{\circ} \mathrm{C}=22.41 \times 298 / 273$ (Ref. A1) and $1 \mathrm{~atm}$ $=24.5$ liters

12 Molecular weight of benzene (Ref. A2) = $78 \mathrm{~g} / \mathrm{g}$ mole

13 Benzene used in the deflagration $=283.5 \mathrm{gal} \times 3.78 \mathrm{1} / \mathrm{gal}$ $1 / 880 \mathrm{~g}$ $\mathrm{g}$ mole $/ 24.51 \times 78 \mathrm{~g} / \mathrm{g}$ mole $\mathrm{x}$ $=3.88$ liters

14 Total Benzene used in the deflagration and present in the liquid phase $=8.92+3.88$

$=12.8$ liters

15 Benzene available for release in the vapor phase during deflagration $=75.6-12.8$

$=62.8$ liters

16 Respirable fraction ( $\leq 10$ micron) of liquid phase released during deflagration (Ref. A5)

$$
=43.1 \mathrm{~kg}
$$

17 The density of the liquid phase is assumed to be $1.0 \mathrm{~kg} / \mathrm{l}$

18 Benzene released during deflagration from the liquid phase

$$
\begin{aligned}
& =43.1 \mathrm{~kg} \mathrm{X} 1.0 \mathrm{~kg} / 1 \times 173 \mathrm{mg} / \mathrm{l} \\
& \times \mathrm{g} / 1000 \mathrm{mg} \times 1 / 880 \mathrm{~g} \\
& =0.008 \text { liters }
\end{aligned}
$$

19 Total benzene released during deflagration

$$
\begin{aligned}
& =62.8+0.008 \text { liters } \\
& =62.808 \text { liters }
\end{aligned}
$$

The release of benzene from the rupture of the simulant Feed Tank would be instantaneous. The toxic chemical hazard methodology (Ref. A6) allows the use of peak 15 minute average concentration for facility, onsite, and offsite comparison with the guidelines.

20 Peak 15 minute average benzene release rate $=62.8081 \times 880 \mathrm{~g} / 1 \times 1 / 900 \mathrm{sec}$. 


$$
\begin{aligned}
& \text { x } 1000 \mathrm{mg} / \mathrm{g} \\
& =6.1 \mathrm{E}+4 \mathrm{mg} / \mathrm{sec} \text {. }
\end{aligned}
$$

21 The benzene release rate for the entire Feed Tank Spill Accident (Accident 4.2) (Ref. A7)

$$
=1.23 \mathrm{E}+6 \mathrm{mg} / \mathrm{sec}
$$

22 The ratio of release rate from the Peak 15 minute average during deflagration and entire Feed Tank spill accident $=6.1 \mathrm{E}+4 / 1.23 \mathrm{E}+6$

$$
=0.05
$$

The facility ( 10 meter), onsite (100 meter), and offsite benzene concentration from the Entire Feed Tank Spill/Fire accident are $6.28 \mathrm{E}+3$, $5.35 \mathrm{E}+3$, and $8.63 \mathrm{E}+0 \mathrm{mg} / \mathrm{m}^{3}$, respectively (Table 7 and 2).

23 Facility benzene concentration during

$$
\begin{aligned}
\text { deflagration } & =6.28 \mathrm{E}+3 \mathrm{mg} / \mathrm{m}^{3} \times 0.05 \\
& =3.14 \mathrm{E}+2 \mathrm{mg} / \mathrm{m}^{3}
\end{aligned}
$$

24 Onsite benzene concentration during deflagration

$$
\begin{aligned}
& =5.35 \mathrm{E}+3 \mathrm{mg} / \mathrm{m}^{3} \times 0.05 \\
& =2.67 \mathrm{E}+2 \mathrm{mg} / \mathrm{m}^{3}
\end{aligned}
$$

25 Offsite benzene concentration during deflagration

$$
\begin{aligned}
& =8.63 \mathrm{E}+0 \mathrm{mg} / \mathrm{m}^{3} \times 0.05 \\
& =4.31 \mathrm{E}-1 \mathrm{mg} / \mathrm{m}^{3}
\end{aligned}
$$

The onsite and offsite increase in lifetime Incremental Cancer Risk (ICR) values from benzene for the Entire Feed Tank Spill/Fire accident are $6.0 \mathrm{E}-5$ and $9.6 \mathrm{E}-8$, respectively (Table 6 ).

26 Onsite ICR from benzene

27 Offsite ICR from benzene

$$
\begin{aligned}
& =6.0 \mathrm{E}-5 \times 0.05 \\
& =3.0 \mathrm{E}-6 \\
& =9.6 \mathrm{E}-8 \times 0.05 \\
& =4.8 \mathrm{E}-9
\end{aligned}
$$


The facility benzene concentration from an instantaneous release during deflagration is also compared against the benzene exposure during normal operation.

28 Action limit for benzene (Ref. A8) $=1.60 \mathrm{mg} / \mathrm{m}^{3}(0.5 \mathrm{ppm})$

29 The average breathing rate for adults (Ref. A6) $=20 \mathrm{~m}^{3} / \mathrm{day}$

30 Working day

$$
\begin{aligned}
& =8 \mathrm{hr} / 24 \mathrm{hr} / \mathrm{day} \\
& =1 / 3 \text { day }
\end{aligned}
$$

31 Exposure per working day during $=1.60 \mathrm{mg} / \mathrm{m}^{3} \times 20 \mathrm{~m}^{3} / \mathrm{day}$ normal operation $1 / 3$ day $=10.7 \mathrm{mg}$

32 Facility benzene concentration for $=3.14 \mathrm{E}+2 \mathrm{mg} / \mathrm{m}^{3} \times 900$ $1 \mathrm{sec}$ release

$$
=2.83 \mathrm{E}+5 \mathrm{mg} / \mathrm{m}^{3}
$$

33 Volume inhaled in $1 \mathrm{sec}$

$$
\begin{aligned}
& =20 \mathrm{~m}^{3} / \text { day } \times \text { day } / 8.64 \mathrm{E}+4 \mathrm{sec} \\
& =2.31 \mathrm{E}-4 \mathrm{~m}^{3}
\end{aligned}
$$

34 Exposure during deflagration

$$
\begin{aligned}
& =2.83 \mathrm{E}+5 \mathrm{mg} / \mathrm{m}^{3} \times 2.31 \mathrm{E}-4 \mathrm{~m}^{3} \\
& =6.55 \mathrm{E}+1 \mathrm{mg}
\end{aligned}
$$

The benzene exposure to a facility individual during benzene deflagration would be about 6 times the one working day exposure during normal operation.

The facility, onsite and offsite benzene concentrations and onsite and offsite ICRs are significantly below the bounding consequences of the Entire Feed Tank Spill/Fire accident. 
References

A1. D. A. Pervis. "Input Data for Safety Evaluation on Acceptance Stripper Tests (U)," WER-ITP-93-1281, September 23, 1993.

A2. Handbook of Chemistry and Physics, CRC Press, 58th Edition.

A3. D. D. Walker, "Consequences of a Stripper Building Stack Deflagration," IWT-LWP-90-0177, September 24, 1990.

A4. Chemical Engineers Handbook, 5th Edition, McGraw-Hill Book Company.

A5. D. A. Kalinich, "Determination of Aerosol Masses Generated by Postulated Explosions in a Simulant Feed Tank at ITP," SRT-PRA939119, September 21, 1993

A6. D. K. Craig, et al., "Toxic Chemical Hazard Classification and Risk Acceptance Guidelines for Use in DOE Facilities," WSRC-MS-92-206, Rev. 1, April, 1993.

A7. M. K. Gupta, "Chemical Consequences of Potential Accidents/ Normal Operation During Filter/Stripper Test Runs and Fast Cruise Using Simulant Solution," SRT-WAG-92-9030, 6/22/93.

A8. National Institute for Occupational Safety and Health, NIOSH Pocket Guide to Chemical Hazards, U. S. Department of Health and Human Services, Washington, DC, June, 1990. 
TABLE 1. COMPOSITION OF SIMULANT SOLUTION (REF. 7)

\begin{tabular}{|c|c|c|c|}
\hline Component & Concentration & (Nominal) & Quantity \\
\hline \multirow[t]{2}{*}{ Salt Solution } & Total $\mathrm{Na}^{+}$ & $4.81 \mathrm{M}$ & up to $12,000 \mathrm{gal}$ \\
\hline & $\begin{array}{c}\mathrm{NaOH} \\
\mathrm{NaNO}_{3} \\
\mathrm{Na}_{2} \mathrm{SO}_{4} \\
\mathrm{NaNO}_{2} \\
\mathrm{Na}_{2} \mathrm{CO}_{3} \\
\mathrm{NaAlO}_{2} \\
\mathrm{KOH}_{3} \\
\mathrm{KNO}_{3}\end{array}$ & $\begin{array}{c}2.57 \mathrm{M} \\
1.35 \mathrm{M} \\
0.015 \mathrm{M} \\
0.39 \mathrm{M} \\
0.01 \mathrm{M} \\
0.45 \mathrm{M} \\
0.036 \mathrm{M} \\
0.16 \mathrm{M}\end{array}$ & \\
\hline STPB & $\mathrm{Na}^{+}$ & $0.55 \mathrm{M}$ & up to $4090 \mathrm{gal}$ \\
\hline Benzene & & & up to $20 \mathrm{gal}$ \\
\hline ST & ST solids & $125 \mathrm{~g} / \mathrm{L}$ & up to $140 \mathrm{gal}$ \\
\hline TBP & & & up to $55 \mathrm{gal}$ \\
\hline
\end{tabular}

\section{NOTES:}

(1) Initial salt concentration was specified to yield a 4.5 molar salt solution after the addition of the ST slurry and the STPB solution.

(2) $\mathrm{KOH}$ and $\mathrm{KNO} 3$ added as a source of potassium for precipitate (KTPB) formation. 


\section{TABLE 2. CONCENTRATION OF VOLATILE CHEMICALS DURING VARIOUS ACCIDENTS}

Accident

\section{Methanol*}

$3.16 \mathrm{E}+4$

\section{|sopropanol}

$3.00 \mathrm{E}+4$

Benzene* $9.57 E+3$

9.57E+3
(3,000 ppm)

$\mathrm{TBP}^{*}$

$1.4 E+3$
125 ppm

(12,000 ppm)

\section{Onsite Concentration $\underline{\mathrm{a}}, \mathrm{mg} / \mathrm{m}^{3}$.}

\section{Offsite Concentration $\underline{\mathrm{bg}}, \mathrm{m}^{3}$}

$\begin{array}{ccccc}\text { Methanol }^{* *} & \text { Isopropanol }^{\star} & \text { Benzene }^{*} & \text { TBP }^{*} & \mathrm{BuOH}^{*} \\ 3.16 \mathrm{E}+2 & 2.53 \mathrm{E}+2 & 9.57 \mathrm{E}+1 & 1.4 \mathrm{E}+1 & 2.4 \mathrm{E}+2\end{array}$

4.1

$\begin{array}{llll}9.79 E-1 & 1.50 E+0 & 2.25 E+2^{d} & 4.47 E-3^{h} \\ & & 5.66 E+1^{e} & \\ 1.99 E+1^{f} & 3.04 E+1^{f} & 5.13 E+2^{g} & 8.94 E-1^{f}\end{array}$

4.2

$2.00 E+0$

1.45E+1

$5.35 E+3$

$3.09 E+0$

$8.05 E+2$

8.30E-1

4.4

$5.31 \mathrm{E}+3^{\mathrm{C}}$

4.5

4.6

4.12
2.67E+2

2.08E-1

$1.33 E+3^{C}$

\section{$2.63 \mathrm{E}+2$}

$\begin{array}{llll}1.58 \mathrm{E}-3 & 2.41 \mathrm{E}-3 & 3.63 \mathrm{E}-1^{\mathrm{d}} & 7.14 \mathrm{E}-6^{\mathrm{h}} \\ & & 9.13 \mathrm{E}-2^{\mathrm{e}} & 1.43 \mathrm{E}-3^{f} \\ 3.21 \mathrm{E}-2^{f} & 4.90 \mathrm{E}-2^{f} & 8.28 \mathrm{E}-19 & \end{array}$

$3.23 \mathrm{E}-3$

2.33E-2

$8.63 E+0$

4.99E-3 1.30E+0

a Onsite: 100 meter from release point; highest 2-hr. X/Q (worst case)

b Offsite: $11.9 \mathrm{~km}$ to the site boundary; highest 2-hr. X/Q (worst case)

$\mathrm{C}$ Concentration inside the stripper building

d Benzene present in STPB solution

e Benzene in 5 gal. bottles; ${ }^{f} 55$ gal. drum spill; 95 gal bottle spill; ${ }^{h}$ TBP in 55 gal drum

* Immediately Dangerous to Life and Health (IDLH) value for Low Hazard Facility

** 0.01 IDLH value for General Use Facility 


\section{TABLE 3. RELEASE TIME OF THE CHEMICALS DURING VARIOUS ACCIDENTS}

Accident

Number

$\frac{\text { Amount }}{\text { Released }} \quad \frac{\text { Release }}{\text { Time }}$

$\mathrm{gm}$

4.1

74

$4,927^{\mathrm{C}}$

$1,078^{\mathrm{C}}$

$4.212,536^{\mathrm{e}}$

$2.9 \mathrm{E}+4^{\mathrm{e}}$

$12,498^{e}$

$3,955^{\ominus}$

4.4

4.12
a pure benzene
$b$ benzene in STPB
c 5 gal. bottle spill
d 0.275 gal.
e liquid phase only
f 55 gal. drum spill

74

215

$705^{c}$
TBP

$\mathrm{BuOH}$

Benzene
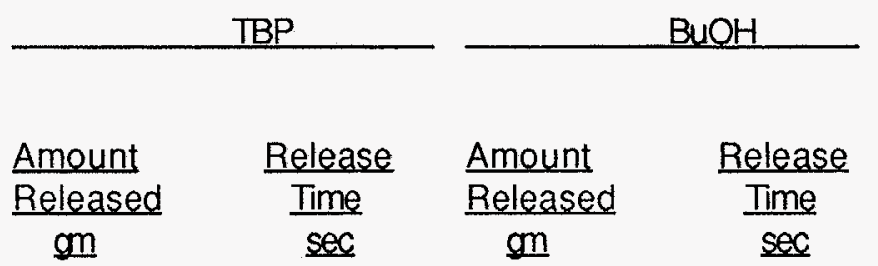

Amount

Released

$\frac{\text { Release }}{\frac{\text { Time }}{\text { sec }}} \quad \frac{\frac{\text { Amount }}{\text { Released }}}{g \mathrm{~m}}$

$\frac{\text { Releas }}{\text { Time }}$

sec

on

sec

$1829^{a} \quad 141^{a}$

$61^{b} \quad 2^{b}$

$16,632^{c} \quad 141^{c}$

$85,600^{\mathrm{e}}$

$73^{e}$

$2.27 E+5^{e}$

$3.36 \mathrm{E}+4^{\mathrm{e}} \quad 1.86 \mathrm{E}+5^{\mathrm{e}}$

$1.06 E+3^{e}$

$85,600^{\mathrm{e}}$

$1.1 \mathrm{E}+4^{\mathrm{e}}$

22,700

375
$1.04 E+3^{d} \quad 1.02 E+6^{d}$

$2.07 E+5^{f}$

$1.02 E+6^{f}$ 


\section{TABLE 4. CONCENTRATION OF NON-VOLATILE CHEMICALS DURING VARIOUS ACCIDENTS}

\begin{tabular}{|c|c|c|c|c|c|c|c|c|}
\hline \multirow[b]{2}{*}{$\begin{array}{l}\text { Accident } \\
\text { Number }\end{array}$} & \multicolumn{4}{|c|}{ Onsite Concentration ${ }^{\mathrm{a}}, \mathrm{mg} / \mathrm{m}^{3}$} & \multicolumn{4}{|c|}{ Offsite Concentration $\underline{\underline{b}}, \mathrm{mg} / \mathrm{m}^{3}$} \\
\hline & $\begin{array}{l}\mathrm{ST} \\
\mathrm{n} / \mathrm{a}\end{array}$ & $\begin{array}{c}\text { STPB } \\
\text { n/a }\end{array}$ & $\begin{array}{c}\mathrm{NaOH} \\
2.0 \mathrm{E}+2^{*}\end{array}$ & $\begin{array}{c}\text { Oxalic } \\
\text { Acid } \\
5.0 \mathrm{E}+2^{*}\end{array}$ & $\begin{array}{l}\mathrm{ST} \\
\mathrm{n} / \mathrm{a}\end{array}$ & $\begin{array}{c}\mathrm{STPB} \\
\mathrm{n} / \mathrm{a}\end{array}$ & $\begin{array}{c}\mathrm{NaOH} \\
2.0 \mathrm{E}+0^{* *}\end{array}$ & $\begin{array}{c}\text { Oxalic } \\
\text { Acid } \\
5.0 \mathrm{E}+0^{* *}\end{array}$ \\
\hline 4.1 & $\begin{array}{c}8.13 E-3 \\
2.70 E-1 c\end{array}$ & $6.93 E-1$ & $9.20 \mathrm{E}-3$ & $3.04 \mathrm{E}-1$ & $\begin{array}{c}1.31 \mathrm{E}-5 \\
4.34 \mathrm{E}-4 \mathrm{C}\end{array}$ & $1.12 \mathrm{E}-3$ & $1.48 \mathrm{E}-5$ & $4.91 \mathrm{E}-4$ \\
\hline 4.2 & $1.38 \mathrm{E}+0$ & $6.19 \mathrm{E}+1$ & & & $2.23 E-3$ & $9.98 \mathrm{E}-2$ & & \\
\hline
\end{tabular}

aOnsite: 100 meter from release point; highest 2-hr. X/Q (worst case) bOffsite: $11.9 \mathrm{~km}$ to the site boundary; highest 2-hr X/Q (worst case) c55 gal. drum spill

* Immediately Dangerous to Life and Health (IDLH) value for Low Hazard facility.

** 0.01 (IDLH) for General Use facility. 
TABLE 5. RADIOLOGICAL CONSEQUENCES OF VARIOUS ACCIDENTS

Onsite Consequences 50-Year Dose. Max. Individual. EDE, rem

Accident

Number
4.9
4.13

$5.4 \mathrm{E}+0^{\mathrm{b}}$

$2.3 \mathrm{E}+0^{\mathrm{b}}$
Offsite Consequences ${ }^{\mathrm{a}}$

50-Year Dose. Max. Individual. EDE. rem

a offsite: $11.9 \mathrm{~km}$ to the site boundary; highest 2-hr X/Q (worst case)

bonsite: 100 meter from release point; highest 2-hr X/Q (worst case) 
TABLE 6. ICR FROM BENZENE FOR AN ONSITE AND OFFSITE INDIVIDUAL

Accident Number

4.1

4.2

4.4

4.5

4.6

4.12

a Benzene present in the STPB solution

b Spill of a entire $5 \mathrm{gal}$. bottle of Benzene

$c$ Inside the stripper building

d Benzene in 5 gal. bottle
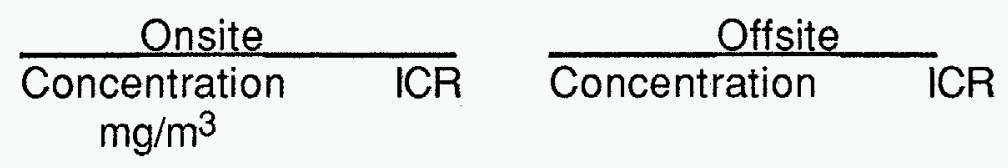

$2.25 \mathrm{E}+2^{\mathrm{a}}$

2.5E-6

$3.63 E-1 a$

4.0E-9

$5.13 \mathrm{E}+2^{\mathrm{b}}$

5.7E-6

$5.66 \mathrm{E}+1 \mathrm{~d}$

$6.3 \mathrm{E}-7 \mathrm{~d}$

8.28E-1b

$9.13 E-2^{d}$

9.2E-9

$5.35 E+3$

$6.0 E-5$

$8.63 E+0$

9.6E-8

3.60E-1

$2.30 \mathrm{E}+3 \mathrm{C}$

4.0E-9

2.5E-5

2.67E+2

3.0E-6

1.81E-2

2.0E-10

$2.08 \mathrm{E}-1$

1.33E+3c

2.3E-9

1.5E-5

2.63E+2

2.9E-6

4.24E-1

4.8E-9 


\section{TABLE 7. FACILITY CONCENTRATIONa OF VOLATILE CHEMICALS DURING VARIOUS ACCIDENTS}

$\begin{array}{ccccc}\text { Methanol }^{*} & \text { Isopropanol }^{*} & \text { Benzene }^{*} & \text { IBP } & \text { BuOH } \\ 3.16 \mathrm{E}+4 \mathrm{mg} / \mathrm{m}^{3} & 3.00 \mathrm{E}+4 \mathrm{mg} / \mathrm{m}^{3} & 9.57 \mathrm{E}+3 \mathrm{mg} / \mathrm{m}^{3} & 1.40 \mathrm{E}+3 \mathrm{mg} / \mathrm{m}^{3} & 2.4 \mathrm{E}+4 \mathrm{mg} / \mathrm{m}^{3} \\ (25,000 \mathrm{ppm}) & (12,000 \mathrm{ppm}) & (3000 \mathrm{ppm}) & (125 \mathrm{ppm}) & (8000 \mathrm{ppm})\end{array}$

Accident Number

\begin{tabular}{|c|c|c|c|c|}
\hline 4.1 & $\begin{array}{c}4.55 \mathrm{E}-1 \\
3.26 \mathrm{E}+2^{b}\end{array}$ & $\begin{array}{c}7.25 \mathrm{E}+1 \\
5.28 \mathrm{E}+2^{b}\end{array}$ & $\begin{array}{l}4.80 E+1^{d} \\
1.59 E+3^{f} \\
1.75 E+2^{e}\end{array}$ & $1.23 E+1 b$ \\
\hline 4.2 & $2.78 \mathrm{E}+1$ & $3.75 \mathrm{E}+1$ & $6.28 \mathrm{E}+3$ & $1.1 \mathrm{E}+1$ \\
\hline 4.5 & & & $3.14 E+2$ & \\
\hline 4.12 & & & $7.37 E+1^{c}$ & \\
\hline
\end{tabular}

a 10 meters from release point

b 55 gal. drum spill

c 20 meters from release point

d Benzene in STPB solution

e Benzene in 5 gal. bottle

f 5 gal. bottle spill

* Immediately Dangerous to Life and Health (IDLH) value (equivalent to Low Hazard Facility) $-56-$ 
TABLE 8. MAXIMUM CONCENTRATIONS IN PARTS PER MILLION (PPM) - 8 HR. AVERAGING

\begin{tabular}{|c|c|c|c|c|}
\hline \multirow[b]{3}{*}{$\begin{array}{l}\text { Filtrate Transfer Release } \\
\text { (Pump out) }\end{array}$} & & \multicolumn{2}{|r|}{$\begin{array}{c}\mathrm{BuOH} \\
(50 \mathrm{ppm})^{\star \star}\end{array}$} \\
\hline & $241-96 \mathrm{H}^{\mathrm{a}}$ & Surrounding Area ${ }^{b}$ & $241-96 \mathrm{H}^{\mathrm{a}}$ & Surrounding Area ${ }^{b}$ \\
\hline & 64 & 0.5 & 9.5 & 0.04 \\
\hline During pump operation & 5 & 0.05 & 0.8 & 0.008 \\
\hline Thermal Cycling 24 hrs. & 0.7 & 0.01 & 0.1 & 0.003 \\
\hline
\end{tabular}

* OSHA Action Level

** OSHA TWA

a Worst case estimate based on interaction of Feed Tank plume with Building $241-96 \mathrm{H}$ (filter-stripper building) during southeasterly winds.

b Highest values from receptor grids located beyond the immediate influence of building $241-96 \mathrm{H}$ (greater than 30 meters downwind of the Feed Tank). 


\section{TABLE 9: MAXIMUM CONCENTRATIONS IN PARTS PER MILLION (PPM) - 1-HR AVERAGING}

\begin{tabular}{|c|c|c|c|c|}
\hline & & \\
\hline & ${\underline{241-96 H^{a}}}^{a}$ & Surrounding Area ${ }^{b}$ & $\underline{241-96 \mathrm{H}^{\mathrm{a}}}$ & Surrounding Area ${ }^{b}$ \\
\hline $\begin{array}{l}\text { Filtrate Transfer Release } \\
\text { (Pump out) }\end{array}$ & 511 & 3.9 & 73 & 0.5 \\
\hline During pump operation & 16 & 0.1 & 2.6 & 0.02 \\
\hline Thermal Cycling $24 \mathrm{hrs}$ & 3.7 & 0.02 & 0.7 & 0.004 \\
\hline
\end{tabular}

a Worst case estimate based on interaction of Feed Tank plume with Building $241-96 \mathrm{H}$ (filter/stripper building) during southeasterly winds.

b Highest values from receptor grids located beyond the immediate influence of Building $241-96 \mathrm{H}$ (greater than 30 meters downwind of the Feed Tank) 


\section{TABLE 10: COMPOSITION OF INFORMATION ONLY SIMULANT SOLUTION}

Salt Solution

(Nominal Concentration of

constituents)

$$
\begin{gathered}
\mathrm{NaOH} \\
\mathrm{NaNO}_{3} \\
\mathrm{Na}_{2} \mathrm{SO}_{4} \\
\mathrm{NaNO}_{2} \\
\mathrm{Na}_{2} \mathrm{CO}_{3} \\
\mathrm{NaAlO}_{2} \\
\mathrm{KOH} \\
\mathrm{KNO}_{3}
\end{gathered}
$$

Benzene

TBP and/or BuOH, DBP, MBP
$2.5-3.0 \mathrm{M}$

$$
\begin{gathered}
2.57 \mathrm{M} \\
1.35 \mathrm{M} \\
0.015 \mathrm{M} \\
0.39 \mathrm{M} \\
0.01 \mathrm{M} \\
0.45 \mathrm{M} \\
0.036 \mathrm{M} \\
0.16 \mathrm{M}
\end{gathered}
$$

$\leq 300$ ppm (per TA)

$\leq 10$ gallons 


\section{TABLE 11: COMPOSITION OF INHIBITED WATER}

Inhibited Water (caustic $0.1 \mathrm{M}$ )

Benzene
5000 gal

$\leq 50 \mathrm{ppm}$ 
TABLE 12. COMPOSITION OF SPENT SIMULANT SOLUTION

\begin{tabular}{|c|c|c|c|}
\hline Component & Concentration & (Nominal) & Quantity \\
\hline \multirow[t]{2}{*}{ Salt Solution } & Total $\mathrm{Na}^{+}$ & $4.81 \mathrm{M}$ & up to $7500 \mathrm{gal}$ \\
\hline & $\begin{array}{c}\mathrm{NaOH} \\
\mathrm{NaNO}_{3} \\
\mathrm{Na}_{2} \mathrm{SO}_{4} \\
\mathrm{NaNO}_{2} \\
\mathrm{Na}_{2} \mathrm{CO}_{3} \\
\mathrm{NaAlO}_{2} \\
\mathrm{KOH}_{3} \\
\mathrm{KNO}_{3}\end{array}$ & $\begin{array}{c}2.57 \mathrm{M} \\
1.35 \mathrm{M} \\
0.015 \mathrm{M} \\
0.39 \mathrm{M} \\
0.01 \mathrm{M} \\
0.45 \mathrm{M} \\
0.036 \mathrm{M} \\
0.16 \mathrm{M}\end{array}$ & \\
\hline STPB & $\mathrm{Na}^{+}$ & $0.55 \mathrm{M}$ & up to $4090 \mathrm{gal}$ \\
\hline Benzene & & & up to $15 \mathrm{ppm}$ \\
\hline ST & ST solids & $125 \mathrm{~g} / \mathrm{L}$ & up to $140 \mathrm{gal}$ \\
\hline TBP & & & up to $25 \mathrm{gal}$ \\
\hline Methanol & & & up to $308 \mathrm{ppm}$ \\
\hline Isopropanol & & & up to $331 \mathrm{ppm}$ \\
\hline
\end{tabular}

NOTES:

(1) Initial salt concentration was specified to yield a 4.5 molar salt solution after the addition of the ST slurry and the STPB solution.

(2) $\mathrm{KOH}$ and $\mathrm{KNO} 3$ added as a source of potassium for precipitate (KTPB) formation. 


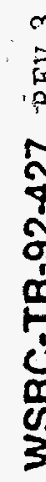

密
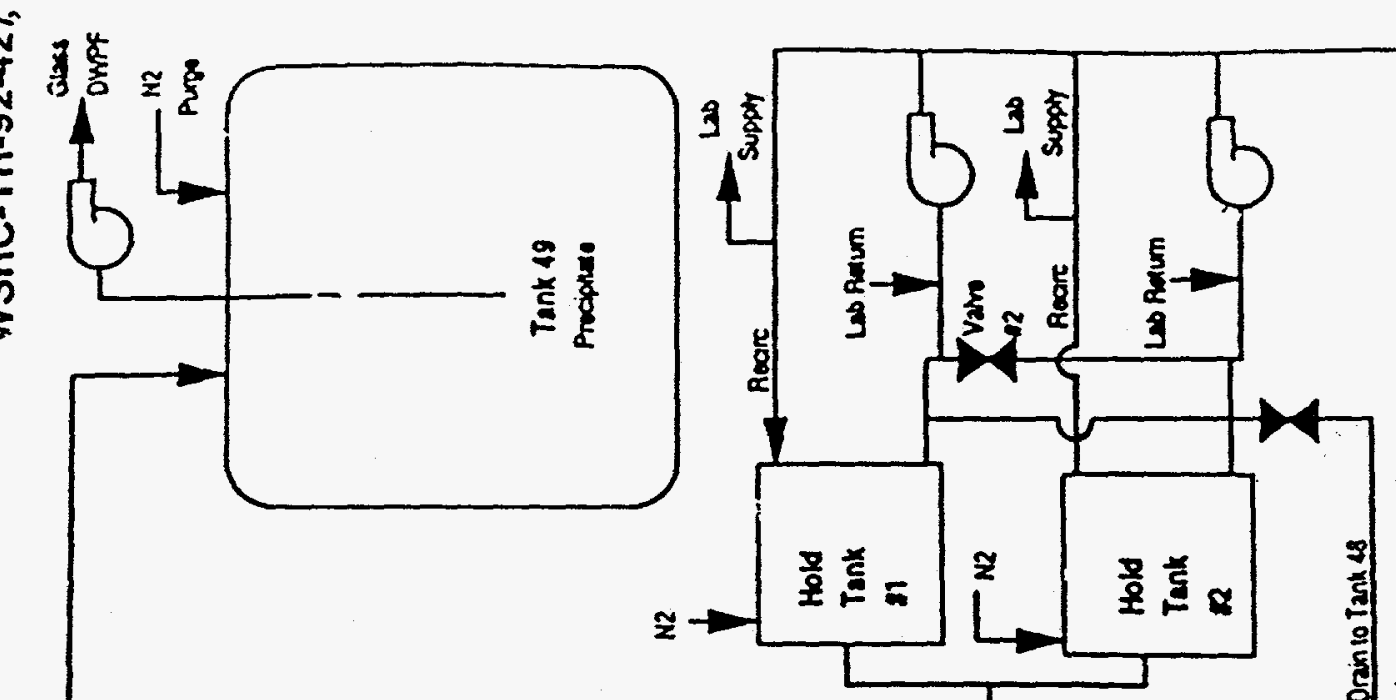

$4 \begin{aligned} & 8 \\ & 5 \\ & 5\end{aligned}$

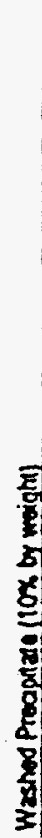
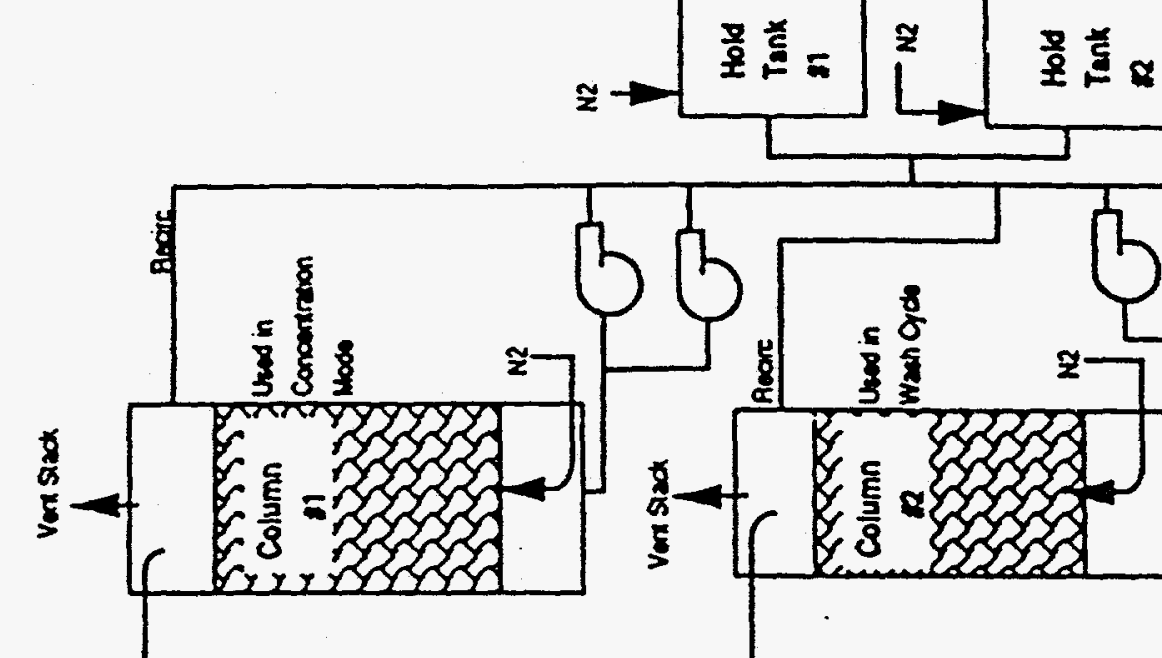

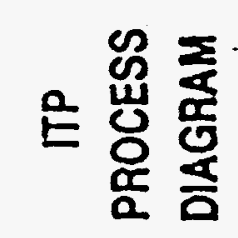
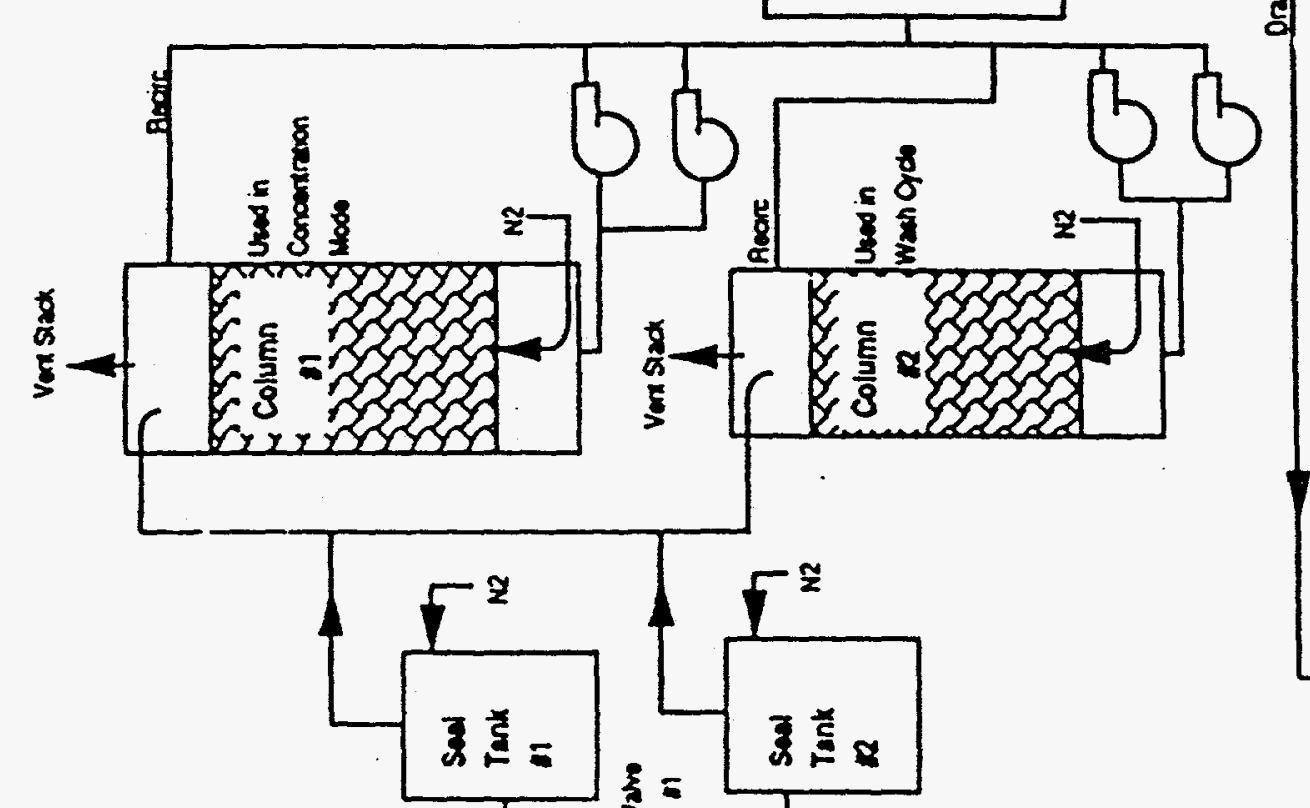


\section{LAYOUT OF TEMPORARY AND PERMANENT FACILITIES}

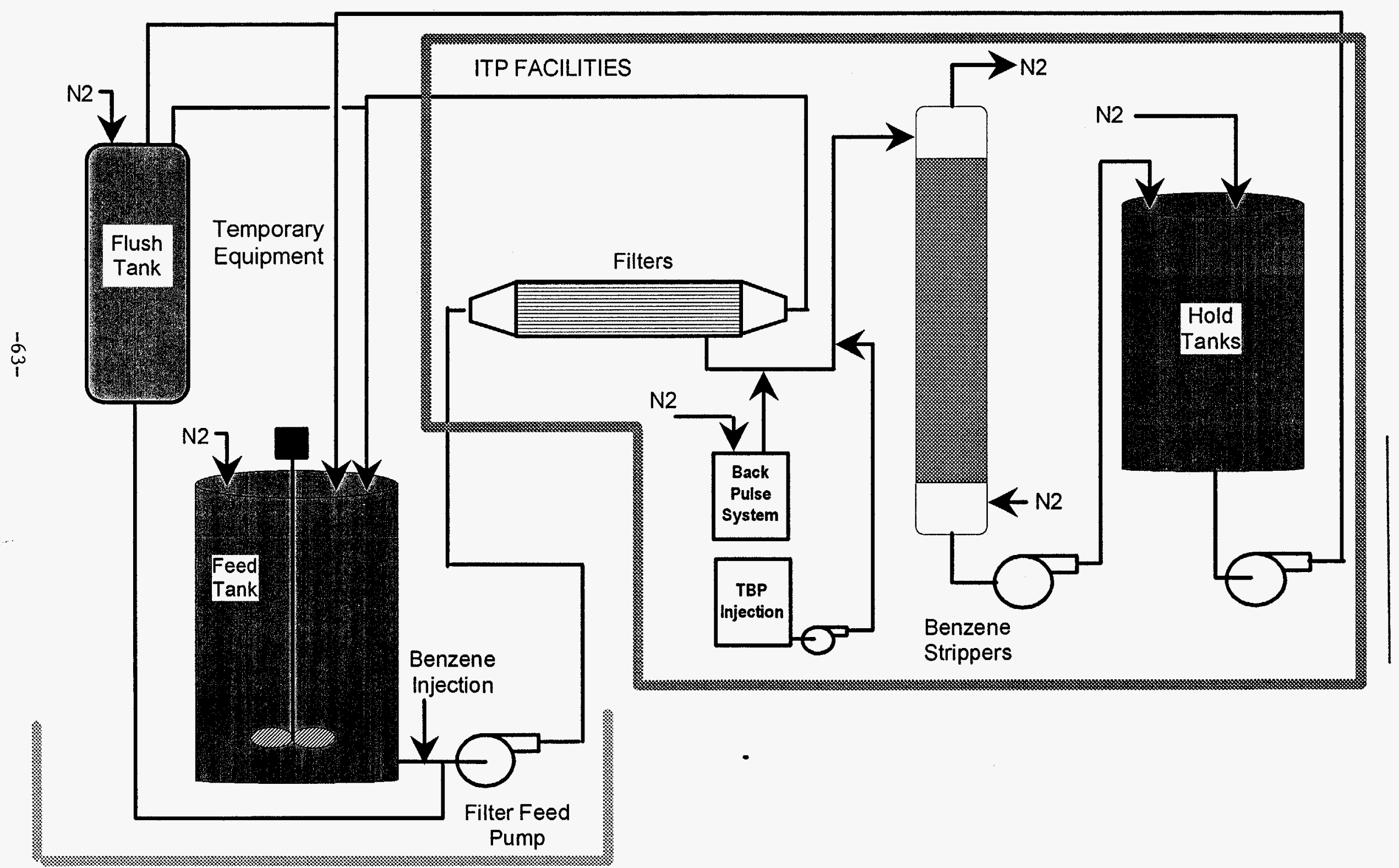

Figure 2. ITP Simulant Run Facility 


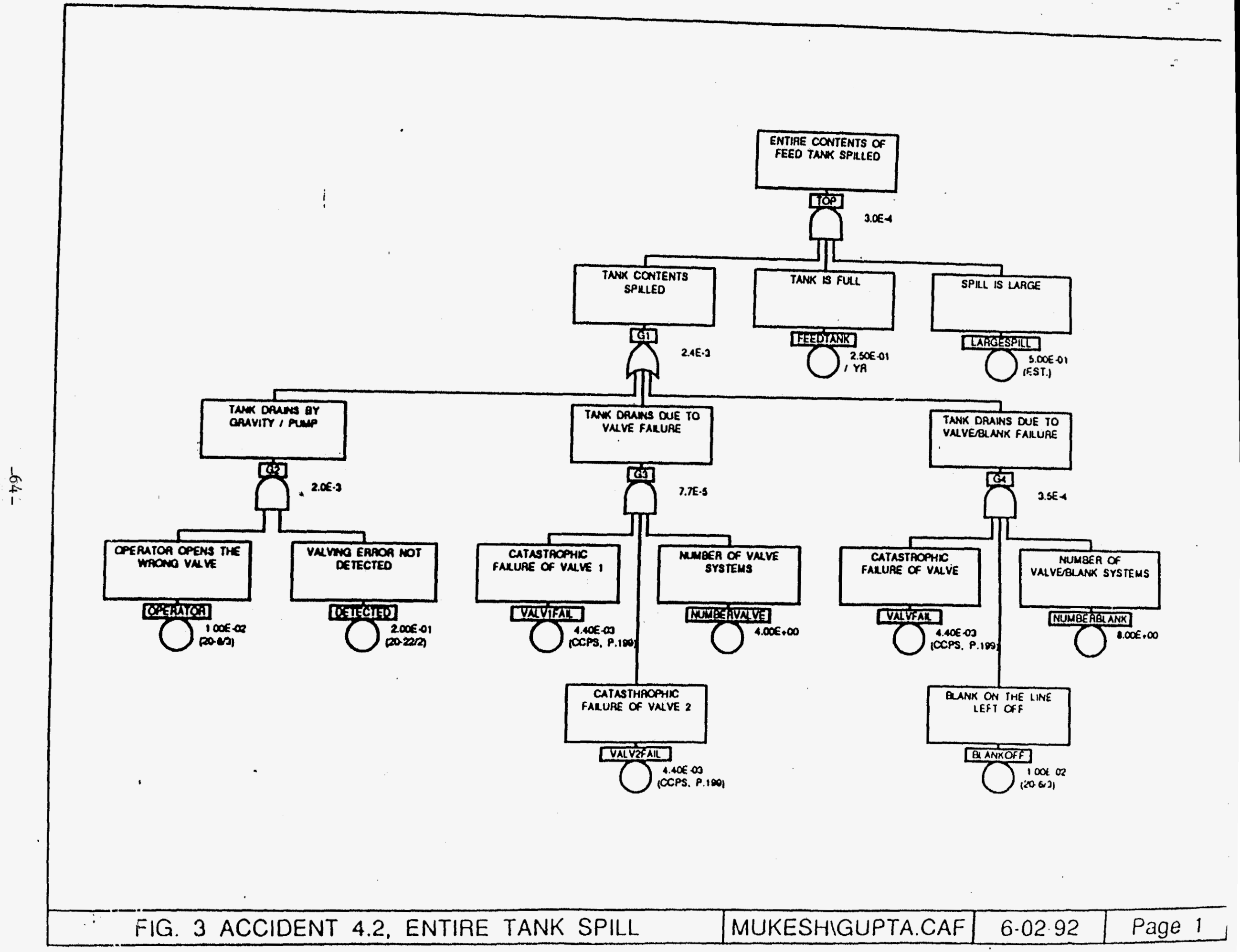


WSRC-TR-92-427, Rev. 3

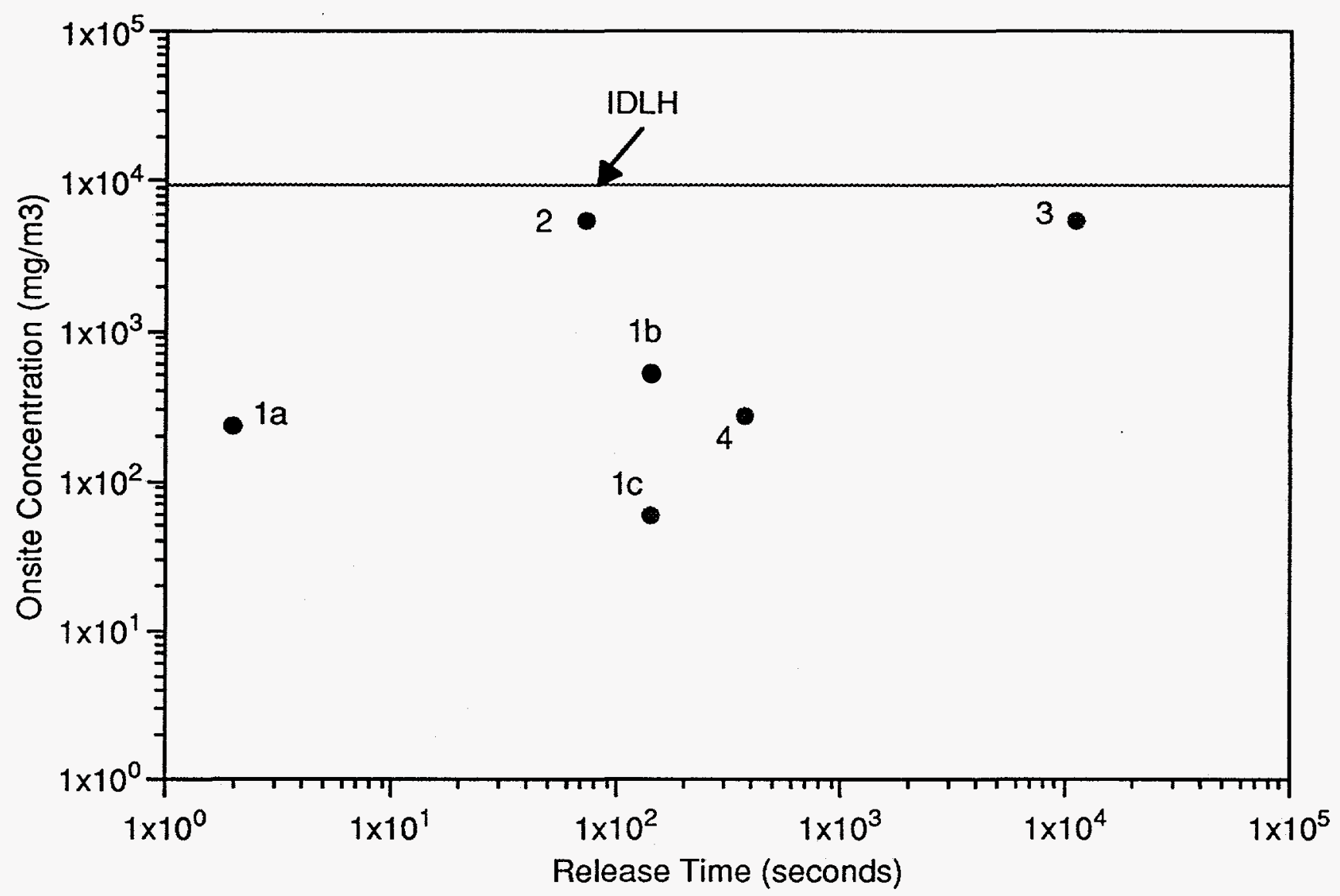

1. Chemical Spills

1a. Benzene in STPB

1b. Spill of 5 gal Benzene Bottle

1c. Benzene in 5 gal Bottles

2. Feed Tank Spill/Fire

3. Benzene Release into Stripper Building

4. Flush Solution Inadvertently Added to Feed Tank

Figure 4. Onsite Benzene Concentration for Potential Accidents 
WSRC-TR-92-427, Rev. 3

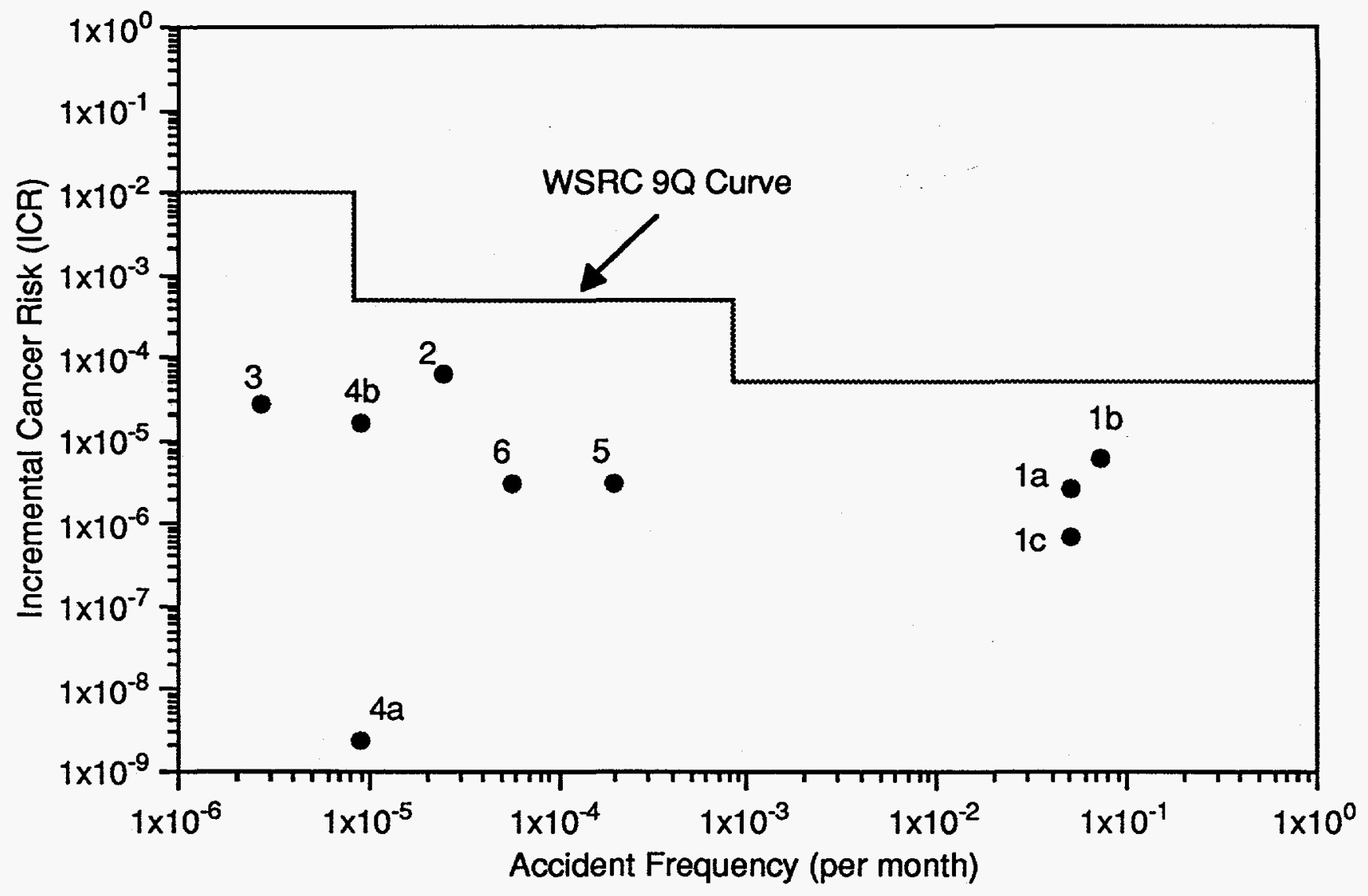

1. Chemical Spills

1a. Benzene in STPB

1b. Spill of 5 gal Benzene Bottle

1c. Benzene in 5 gal Bottles

2. Feed Tank Spill/Fire

3. Benzene Release into Stripper Building

4. Benzene Deflagration Release During Column Cleaning 4a. Release Through Stack 4b. Release into Stripper Building

5. Flush Solution Inadvertently Added to Feed Tank

6. Benzene/Butanol Deflagration in Feed Tank

Figure 5. Onsite ICR from Benzene for Potential Accidents 


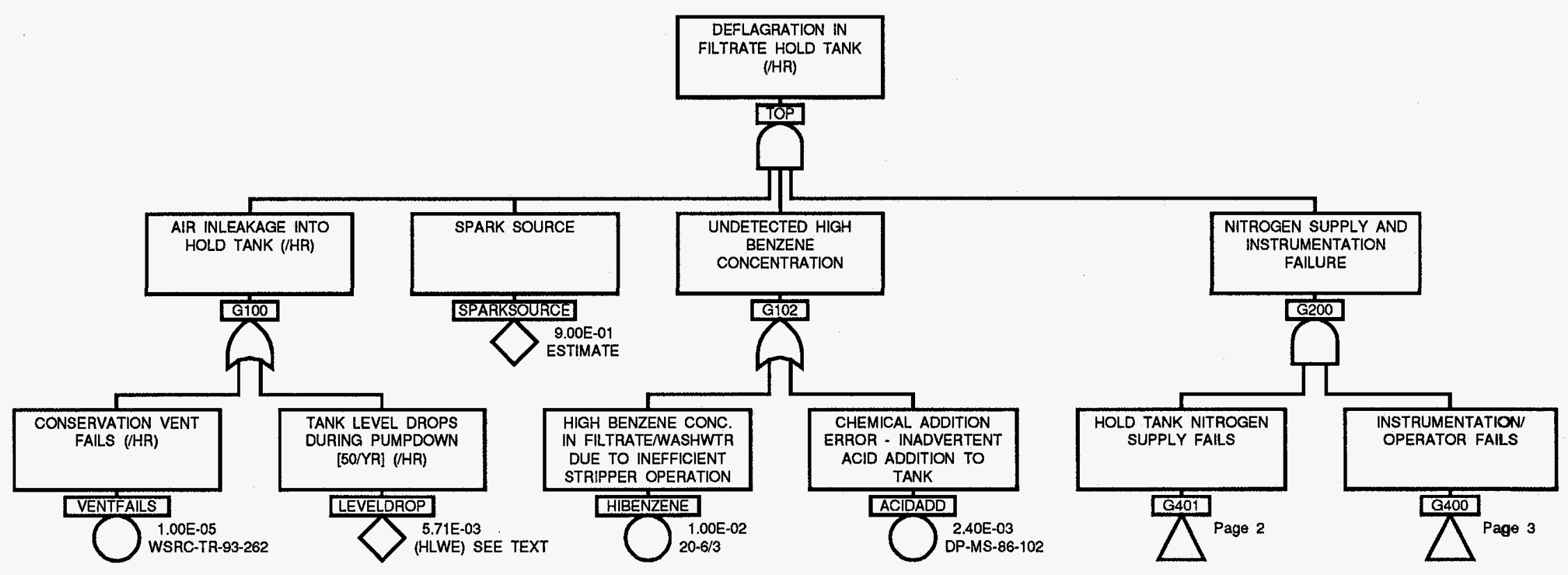

FIG. 6 ACCIDENT NO. 4.11 DEFLAG. IN FHT 


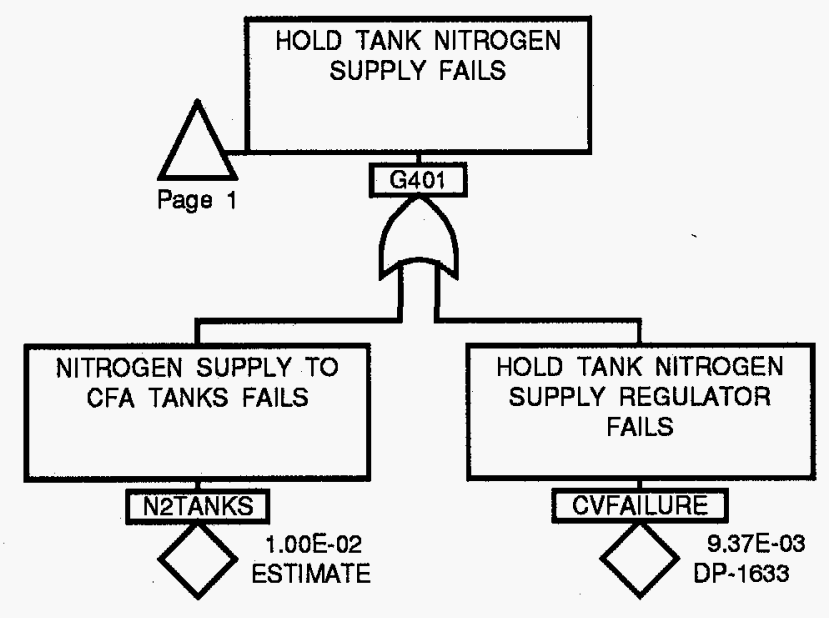




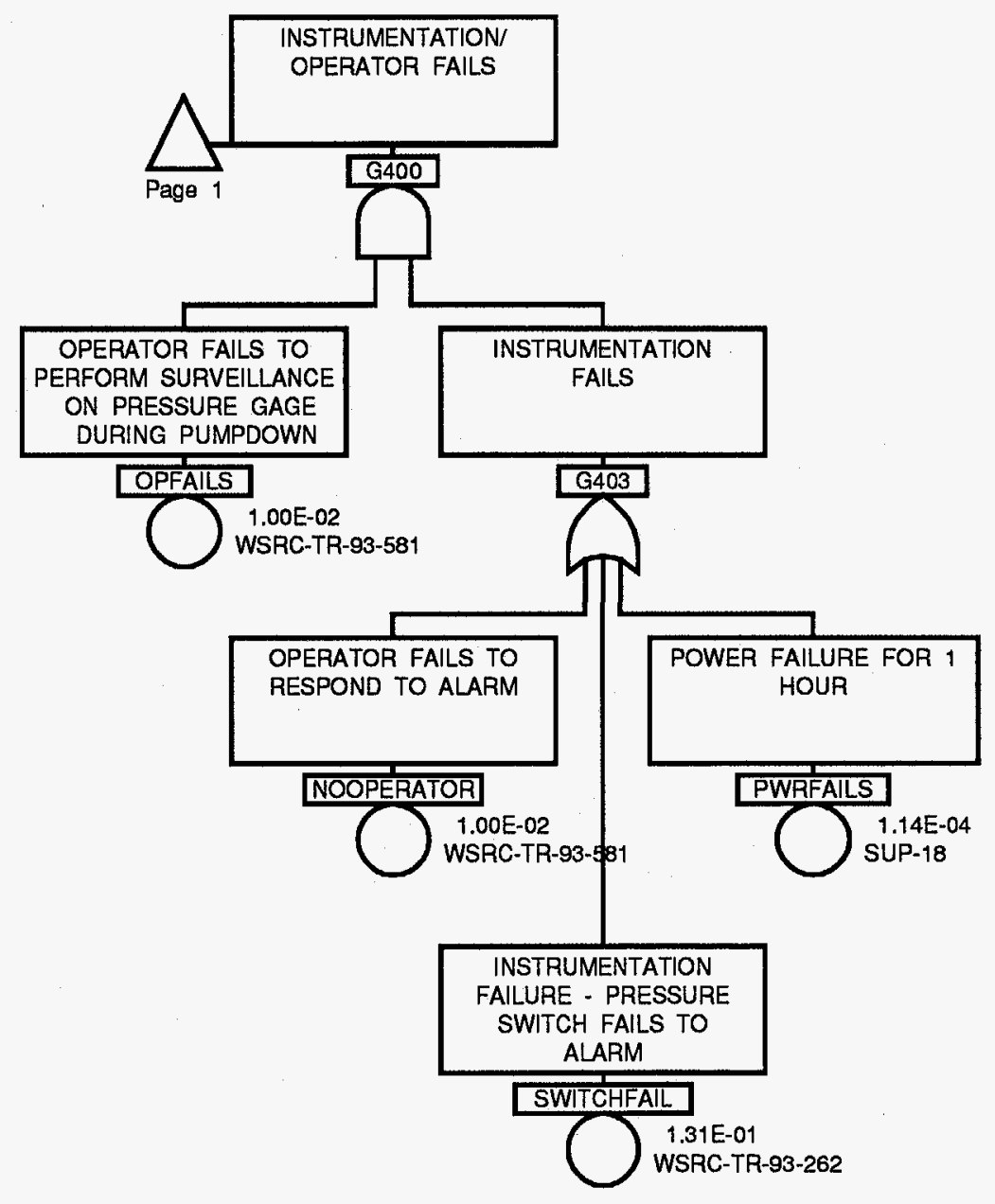




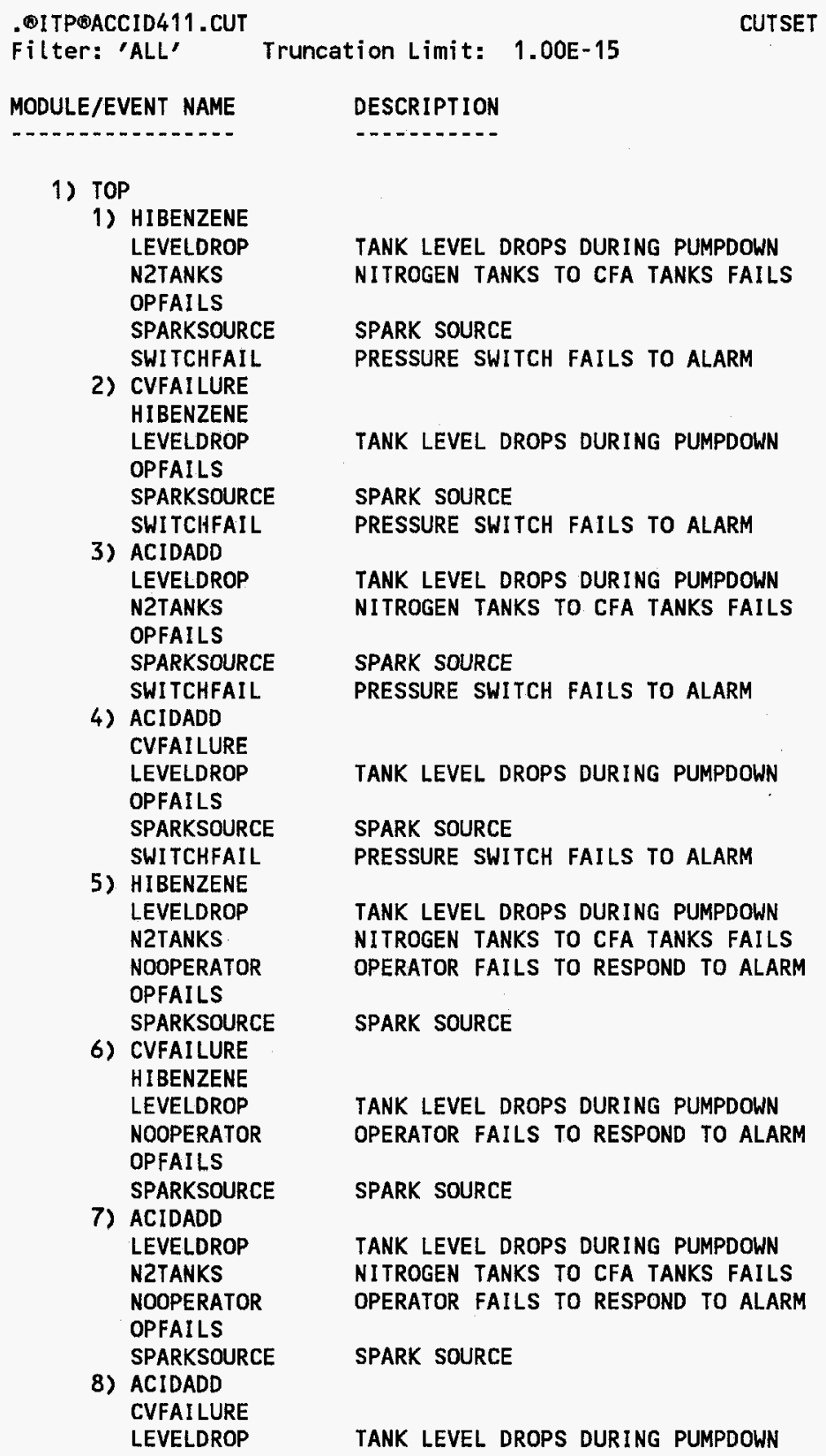

5/16/94 13:44 Page 1

RATE B.E. EXPOSURE PROB.

MOD./CS.

$\begin{array}{lll} & & * 1.75 E-09 \\ 1.00 E-02 & 1.00 E-02 & 6.75 E-10 \\ .114 & 5.71 E-03 & \\ .001 & 1.00 E-02 & \\ 1.00 E-02 & 1.00 E-02 & \\ .9 & 9.00 E-01 & \\ .085 & 1.31 E-01 & \\ 9.37 E-03 & 9.37 E-03 & 6.33 E-10 \\ 1.00-02 & 1.00 E-02 & \\ .114 & 5.71 E-03 & \\ 1.00 E-02 & 1.00 E-02 & \\ .9 & 9.00 E-01 & \\ .085 & 1.31 E-01 & \\ 2.40 E-03 & 2.40 E-03 & 1.62 E-10 \\ .114 & 5.71 E-03 & \\ .001 & 1.00 E-02 & \\ 1.00 E-02 & 1.00 E-02 & \\ .9 & 9.00 E-01 & \\ .085 & 1.31 E-01 & \\ 2.40 E-03 & 2.40 E-03 & 1.52 E-10 \\ 9.37 E-03 & 9.37 E-03 & \\ .114 & 5.71 E-03 & \\ 1.00 E-02 & 1.00 E-02 & \\ .9 & 9.00 E-01 & \\ .085 & 1.31 E-01 & \\ 1.00 E-02 & 1.00 E-02 & 5.14 E-11 \\ .114 & 5.71 E-03 & \\ .001 & 1.00 E-02 & \\ .005 & 1.00 E-02 & \\ 1.00 E-02 & 1.00 E-02 & \\ .9 & 9.00 E-01 & \\ 9.37 E-03 & 9.37 E-03 & 4.82 E-11 \\ 1.00 E-02 & 1.00 E-02 & \\ .114 & 5.71 E-03 & \\ .005 & 1.00 E-02 & \\ 1.00 E-02 & 1.00 E-02 & \\ .9 & 9.00 E-01 & \\ 2.40 E-03 & 2.40 E-03 & 1.23 E-11 \\ .114 & 5.71 E-03 & \\ .001 & 1.00 E-02 & \\ .005 & 1.00 E-02 & \\ 1.00 E-02 & 1.00 E-02 & \\ .9 & 9.00 E-01 & \\ 2.40 E-03 & 2.40 E-03 & 1.16 E-11 \\ 9.37 E-03 & 9.37 E-03 & \\ .114 & 5.71 E-03 & \\ & & \\ & & \\ & \end{array}$


NOOPERATOR OPFAILS

SPARKSOURCE

9) HIBENZENE

N2TANKS

OPFAILS

SPARKSOURCE

SWITCHFAIL

OPERATOR FAILS TO RESPOND TO ALARM

SPARK SOURCE

NITROGEN TANKS TO CFA TANKS FAILS

SPARK SOURCE

PRESSURE SWITCH FAILS TO ALARM

\begin{tabular}{|c|c|c|}
\hline $\begin{array}{l}.005 \\
1.00 \mathrm{E}-02 \\
.9 \\
1.00 \mathrm{E}-02 \\
.001 \\
1.00 \mathrm{E}-02 \\
.9 \\
.085\end{array}$ & $\begin{array}{l}1.00 E-02 \\
1.00 E-02 \\
9.00 E-01 \\
1.00 E-02 \\
1.00 E-02 \\
1.00 E-02 \\
9.00 E-01 \\
1.31 E-01\end{array}$ & $1.18 E-12$ \\
\hline
\end{tabular}

$\begin{array}{ll}.005 & 1.00 \mathrm{E}-02 \\ 1.00 \mathrm{E}-02 & 1.00 \mathrm{E}-02\end{array}$

$.9 \quad 9.00 \mathrm{E}-01$

1.00E-02 $1.18 \mathrm{E}-12$

$.085 \quad 1.31 \mathrm{E}-0$ 
OITPOACCID411.CUT Filter: 'ALL' Truncation Limit: $1.00 \mathrm{E}-15$

CUTSET REPORT

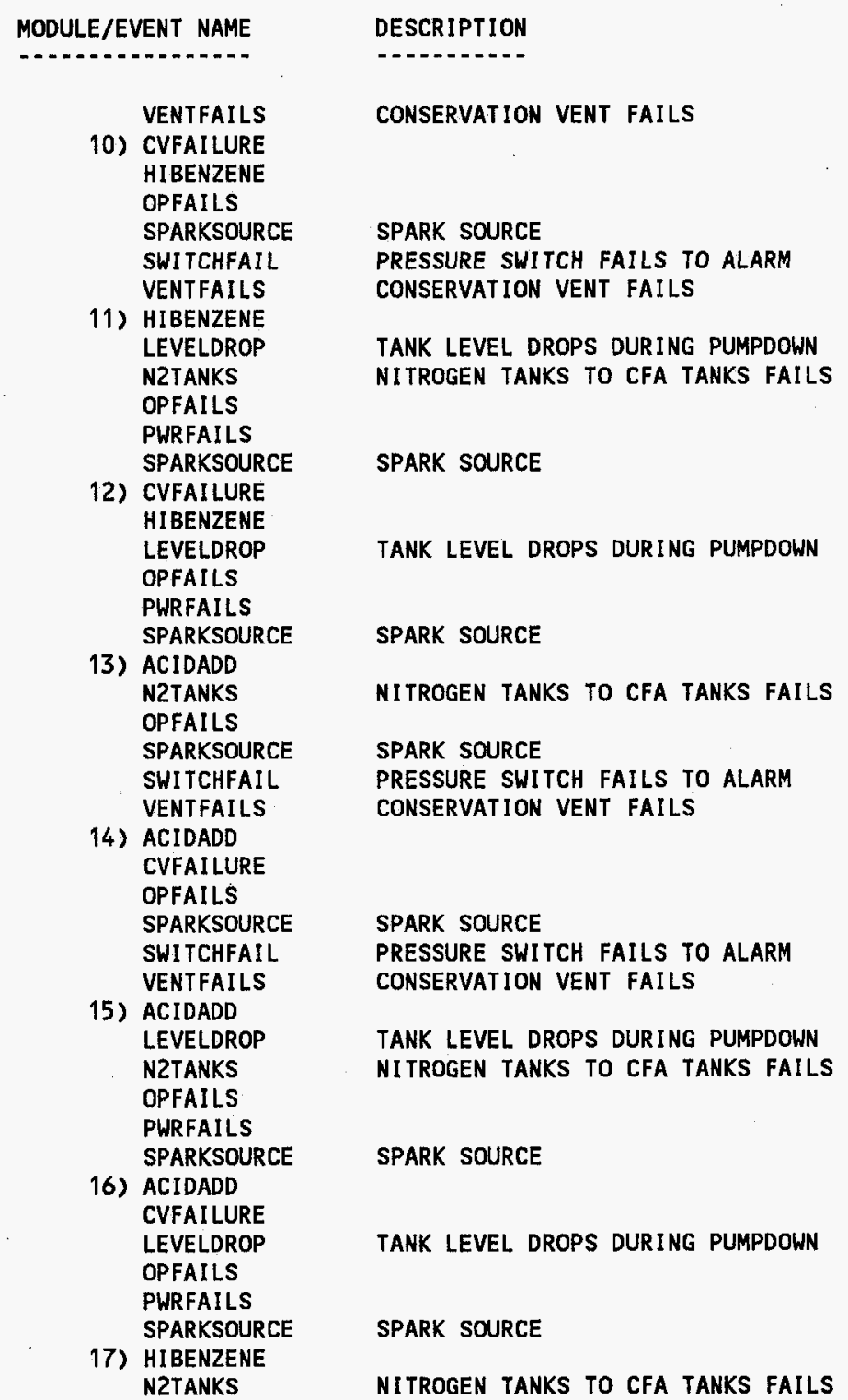

5/16/94 13:44 Page 2

B.E. MOD./CS

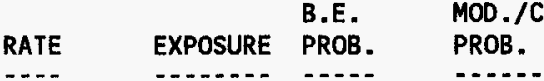

1e-05 1.00E-05

9.37E-03 9.37E-03 1.11E-12

$1.00 E-02 \quad 1.00 E-02$

$1.00 \mathrm{E}-02 \quad 1.00 \mathrm{E}-02$

$9 \quad 9.00 E-01$

$.085 \quad 1.31 \mathrm{E}-01$

$1 \mathrm{e}-05 \quad 1.00 \mathrm{E}-05$

1.00E-02 1.00E-02 5.86E-13

$.114 \quad 5.71 \mathrm{E}-03$

$.001 \quad 1.00 E-02$

$1.00 \mathrm{E}-02 \quad 1.00 \mathrm{E}-02$

$1.14 E-04 \quad 1.14 E-04$

$1.14 \mathrm{E}-04 \quad 1.14 \mathrm{E}-04$

9 9.00E-0

9.37E-03 9.37E-03 5.49E-13

$1.00 \mathrm{E}-02 \quad 1.00 \mathrm{E}-02$

$.114 \quad 5.71 \mathrm{E}-03$

1.00E-02 1.00E-02

$1.14 \mathrm{E}-04 \quad 1.14 \mathrm{E}-04$

$.9 \quad 9.00 \mathrm{E}-01$

$2.40 \mathrm{E}-03 \quad 2.40 \mathrm{E}-03 \quad 2.84 \mathrm{E}-13$

001 1.00E-02

$1.00 \mathrm{E}-02 \quad 1.00 \mathrm{E}-02$

$.9 \quad 9.00 \mathrm{E}-01$

$.085 \quad 1.31 \mathrm{E}-01$

$1 \mathrm{e}-05 \quad 1.00 \mathrm{E}-05$

$2.40 \mathrm{E}-03 \quad 2.40 \mathrm{E}-03 \quad 2.66 \mathrm{E}-13$

9.37E-03 9.37E-03

$1.00 E-02 \quad 1.00 E-02$

9 - $900 \mathrm{E}-02$-02

$.9 \quad 9.00 \mathrm{E}-01$

$.085 \quad 1.31 \mathrm{E}-01$

$\begin{array}{lll}1 \mathrm{e}-05 & 1.00 \mathrm{E}-05 & \\ 2.40 \mathrm{E}-03 & 2.40 \mathrm{E}-03 & 1.41 \mathrm{E}-13\end{array}$

$.114 \quad 5.71 \mathrm{E}-03$

$.001 \quad 1.00 \mathrm{E}-02$

1.00E-02 1.00E-02

$1.14 \mathrm{E}-04 \quad 1.14 \mathrm{E}-04$

9 - $9.14 \mathrm{E}-04$

$\begin{array}{lll}2.40 E-03 & 2.40 E-03 & 1.32 E-13\end{array}$

$9.37 \mathrm{E}-03 \quad 9.37 \mathrm{E}-03$

$.114 \quad 5.71 \mathrm{E}-03$

$1.00 \mathrm{E}-02 \quad 1.00 \mathrm{E}-02$

$1.14 E-04 \quad 1.14 E-04$

$.9 \quad 9.00 \mathrm{E}-01$

$1.00 \mathrm{E}-02 \quad 1.00 \mathrm{E}-02 \quad 9.00 \mathrm{E}-14$

$.001 \quad 1.00 \mathrm{E}-02$ 
NOOPERATOR OPFAILS

SPARKSOURCE

VENTFAILS

18) CVFAILURE

HIBENZENE

NOOPERATOR

OPFAILS

SPARKSOURCE
OPERATOR FAILS TO RESPOND TO ALARM

\section{SPARK SOURCE}

CONSERVATION VENT FAILS

OPERATOR FAILS TO RESPOND TO ALARM

SPARK SOURCE
$.005 \quad 1.00 \mathrm{E}-02$

$1.00 E-02 \quad 1.00 E-02$

$.9 \quad 9.00 E-01$

1e-05 1.00E-05

9.37E-03 9.37E-03 8.43E-14

$1.00 \mathrm{E}-02 \quad 1.00 \mathrm{E}-02$

$.005 \quad 1.00 E-02$

$1.00 \mathrm{E}-02 \quad 1.00 \mathrm{E}-02$

.9 
-OI TPOACCID411:CUT

Filter: 'ALL'

Truncation Limit: $1.00 \mathrm{E}-15$

CUTSET REPORT

\section{MODULE/EVENT NAME OESCRIPTION}

VENTFAILS CONSERVATION VENT FAILS

19) ACIDADD

N2TANKS

NOOPERATOR

OPFAILS

SPARKSOURCE

VENTFAILS

20) ACIDADD

CVFAILURE

OPFAIIS

SPARKSOURCE

VENTFAILS

21) HIBENZENE

N2TANKS

OPFAILS

PWRFAILS

SPARKSOURCE
NI TROGEN TANKS TO CFA TANKS FAILS OPERATOR FAILS TO RESPOND TO ALARM

SPARK SOURCE

CONSERVATION VENT FAILS

OPERATOR FAILS TO RESPOND TO ALARM

SPARK SOURCE

CONSERVATION VENT FAILS

NITROGEN TANKS TO CFA TANKS FAILS

SPARK SOURCE

CONSERVATION VENT FAILS

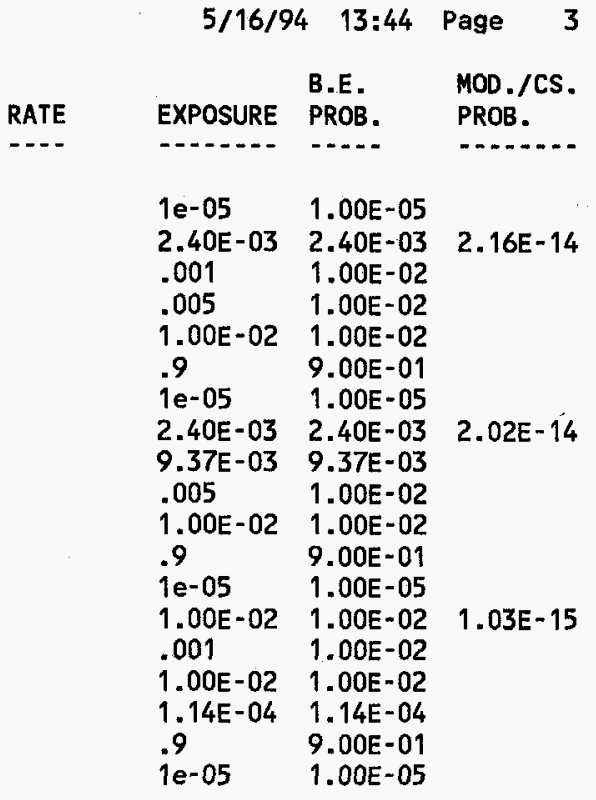


WSRC-TR-92-427, Rev. 3

-I TPФACCID411.CUT

Top event: TOP

Top prob.: $1.75 \mathrm{E}-09$

CUTSET REPORT

5/16/94 13:44 Page

Basic Event Name

ACIDADD $\quad 2.40 E-03$

CVFAILURE 9.37E-03

HIBENZENE $\quad 1.00 E-02$

LEVELDROP $\quad 5.71 \mathrm{E}-03$

N2TANKS $1.00 \mathrm{E}-02$

N2TANKS $\quad 1.00 \mathrm{E}-02$

$\begin{array}{ll}\text { NOOPERATOR } & 1.00 \mathrm{E}-02 \\ \text { OPFAILS } & 1.00 \mathrm{E}-02\end{array}$

PWRFAILS $\quad 1.14 \mathrm{E}-04$

SPARKSOURCE 9.00E-01

SWITCHFAIL

VENTFAILS 


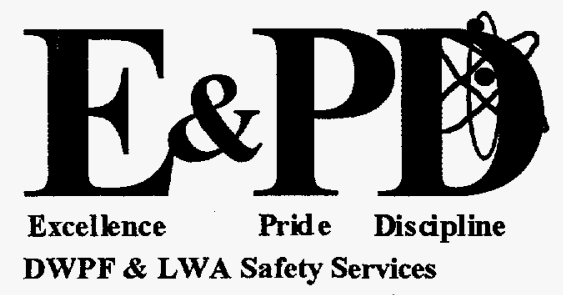

June 6, 1994

EPD-LWS-94-0012

To: $\quad$ B. G. Croley, $241-120 \mathrm{H}$

From: J. D. Menna, 992-1W Your

Safety Evaluation of the ITP Filter/Stripper Test Runs and Quiet Time Runs Using $\underline{\text { Simulant Solution (U) }}$

The E\&PD and WSRC review process for the Safety Evaluation of the ITP Filter/Stripper Test Runs and Quiet Time Runs Using Simulant Solution (U), WSRC-TR-92-427, $\operatorname{Rev} 3$, is complete. The comments were resolved and incorporated as appropriate.

SRTC, E\&PD, ESH\&QA, and Waste Management Safety Review Committee (WMSRC) have approved the document.

If you have any questions, please contact M. K. Gupta of my staff.

CC: $\quad$ G. T. Wright, 703-H

B. L. Lewis, 703-H

G. D. Thaxton, 241-120H

R. M. Satterfield, 719-4A

R. F. Bradley, 992-2W

M. L. Cowen, 992-1W

T. E. Britt, 992-1W

Kyo Kim, 992-2W

D. C. Wood, 706-21C
R. A. Scaggs, 703-H

C. J. Baker, $5002 \mathrm{H}$

W. B. Van Pelt, 241-120H

B. S. Shapiro, 992-1W

D. A. Pervis, 706-21C

M. K. Gupta, 992-1W

V. S. O'Block, 992-2W

H. M. Handfinger, $5002 \mathrm{H}$ 